\title{
Série de
}

TRABALHOS PARA DISCUSSÃO

\section{Working Paper Series}
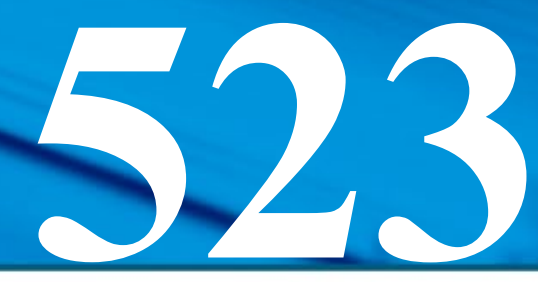

JULY 2020

Unemployment Insurance as a Subsidy to Risky Firms

Bernardus Ferdinandus Nazar Van Doornik, Dimas Mateus Fazio, David Schoenherr, Janis Skrastins 
ISSN 1518-3548

CGC 00.038.166/0001-05 


\section{Working Paper Series}

Edited by the Research Department (Depep) - E-mail: workingpaper@bcb.gov.br

Editor: Francisco Marcos Rodrigues Figueiredo

Co-editor: José Valentim Machado Vicente

Head of the Research Department: André Minella

Deputy Governor for Economic Policy: Fabio Kanczuk

The Banco Central do Brasil Working Papers are evaluated in double blind referee process.

Although the Working Papers often represent preliminary work, citation of source is required when used or reproduced.

The views expressed in this Working Paper are those of the authors and do not necessarily reflect those of the Banco Central do Brasil.

As opiniões expressas neste trabalho são exclusivamente do(s) autor(es) e não refletem, necessariamente, a visão do Banco Central do Brasil.

\section{Citizen Service Division}

Banco Central do Brasil

Deati/Diate

SBS - Quadra 3 - Bloco B - Edifício-Sede - $2^{\circ}$ subsolo

70074-900 Brasília - DF - Brazil

Toll Free: 08009792345

Fax: +55 (61) 3414-2553

Internet: http//www.bcb.gov.br/?CONTACTUS 


\section{Non-Technical Summary}

This paper assesses how unemployment insurance (UI) affects the allocation of labor between safe and risky firms. Risk-taking in pursuit of profitable investment opportunities is a fundamental driver of economic growth. Risk-aversion of individuals may reduce corporate risk-taking below its optimal level. For example, managers' risk-aversion can reduce firms' risk-taking incentives below its value-maximizing level. Similarly, risk preferences of the broader workforce may restrict firms' ability to engage in profitable but risky financing and investment strategies. In this paper, we examine whether a more generous unemployment insurance system increases workers' tolerance for corporate risk-taking.

We exploit a sudden and unanticipated UI reform in Brazil in 2015 that tightened eligibility criteria for part of the workforce. The reform restricted eligibility for workers with fewer than two previous UI benefits spells, which applied to about 60 percent of all workers in the end of 2014. The design of the reform allows us to compare changes in the labor supply within the same firm and month. Specifically, we assess whether riskier firms experience a stronger drop in labor supply than safer firms from workers whose UI eligibility was tightened relative to those whose UI remained unchanged.

We document that UI can act as an external mechanism increasing workers' tolerance for corporate risk taking. Specifically, we show that a more generous UI system shifts labor supply to riskier firms and reduces the compensating wage differential these firms need to pay to attract workers. Lower labor costs increase risky firms' value. We also observe that a more generous UI system encourages entrepreneurship by making it easier for new firms to attract employees.

Our findings provide novel insights to the literature on the optimal UI design. The standard BailyChetty framework characterizes the optimal policy choice as a trade-off between adverse effects of UI on labor supply and welfare gains from protecting individuals against income shocks. Our findings suggest that the UI system acts as a subsidy to risky firms' labor costs and encourages risk-taking in the economy. Since UI systems are typically financed through taxes on labor, they constitute a transfer system from safer to riskier firms, particularly, if UI is not experience-rated. 


\section{Sumário Não Técnico}

Este artigo avalia como o seguro-desemprego (SD) afeta a alocação de trabalho entre firmas seguras e firmas arriscadas. A assunção de riscos em busca de oportunidades de investimento é um fator fundamental para o crescimento econômico. A aversão ao risco dos indivíduos pode reduzir o risco corporativo abaixo do seu nível ideal. Por exemplo, a aversão ao risco dos gerentes pode reduzir os incentivos de tomada de risco das empresas abaixo do seu nível de maximização de valor. Da mesma forma, as preferências de risco dos empregados podem restringir a capacidade das empresas de se engajarem em estratégias de financiamento e investimento lucrativas, porém arriscadas. Neste artigo, é examinado se um sistema de seguro-desemprego mais generoso aumenta a tolerância dos trabalhadores em assumir riscos corporativos.

Para tal, é explorada uma reforma súbita de SD no Brasil em 2015, a qual reforçou os critérios de elegibilidade para parte da força de trabalho. A reforma reforçou os critérios de elegibilidade para trabalhadores com menos de dois períodos anteriores de benefícios do SD, critérios esses que se aplicavam a cerca de $60 \%$ de todos os trabalhadores no final de 2014. A reforma permite comparar as mudanças na oferta de mão de obra dentro da mesma empresa e mês. Especificamente, avaliase se as empresas mais arriscadas experimentam uma queda mais forte na oferta de mão de obra em relação às empresas mais seguras dos trabalhadores cuja elegibilidade do SD foi restrita em relação àqueles cuja regras de SD permaneceram inalteradas.

Documenta-se que o SD pode atuar como um mecanismo externo, aumentando a tolerância dos trabalhadores em assumir riscos corporativos. Especificamente, mostra-se que um sistema de SD mais generoso tende a transferir a oferta de mão de obra para empresas mais arriscadas e reduz o diferencial de salarial compensatório que essas empresas precisam pagar para atrair trabalhadores. Custos de mão de obra mais baixos aumentam o valor das empresas arriscadas. Observa-se também que um sistema de SD mais generoso estimula o empreendedorismo, facilitando a atração de novos funcionários pelas novas empresas.

Essas descobertas fornecem novos insights para a literatura sobre o design de sistemas de SD. A estrutura padrão de Baily-Chetty caracteriza a escolha política ótima como um trade-off entre os efeitos adversos do SD sobre a oferta de trabalho e os ganhos de bem-estar da proteção de indivíduos contra choques de renda. As descobertas desse artigo sugerem que o sistema de SD atua como um subsídio para os custos laborais das empresas arriscadas e encoraja a tomada de risco na economia. Como os sistemas de SD são tipicamente financiados por meio de impostos sobre a mão de obra, eles constituem um sistema de transferência de empresas mais seguras para empresas mais arriscadas, particularmente se o sistema de SD não for ajustado pela utilização do usuário (experience-rated). 


\title{
Unemployment Insurance as a Subsidy to Risky Firms*
}

\author{
Bernardus Ferdinandus Nazar Van Doornik ${ }^{* *}$ \\ Dimas Mateus Fazio*** \\ David Schoenherr ${ }^{* * * *}$
}

Janis Skrastins ${ }^{* * * * *}$

\begin{abstract}
We document that a more generous unemployment insurance (UI) system shifts labor supply from safer to riskier firms and reduces compensating wage differentials risky firms need to pay. Consequently, a more generous UI system increases risky firms' value and fosters entrepreneurship by reducing new firms' labor costs. Exploiting a UI reform in Brazil that affects only part of the workforce allows us to compare labor supply for workers with different degrees of UI protection within the same firm, sharpening identification of the results. Altogether, our results suggest that UI provides a transfer system from safe to risky firms.
\end{abstract}

Keywords: unemployment insurance, labor supply, firm risk, entrepreneurship

JEL Codes: J21, J22, J46, J65, K31

The Working Papers should not be reported as representing the views of the Banco Central do Brasil. The views expressed in the papers are those of the authors and do not necessarily reflect those of the Banco Central do Brasil.

\footnotetext{
*We thank Taylor Begley, Asaf Bernstein, Jennifer Brown, Todd Gormley, Alfred Lehar, Elena Smintzi, David Sraer, Jan Starmans, Anjan Thakor, seminar participants at the Baltic Economic Association, Banco Central do Brasil, Bank of Latvia, Hoover Institution at Stanford, Princeton University, Washington University in St. Louis, Yale University, and participants at the European Winter Finance Summit, 2019 MIT Sloan Junior Finance Faculty Conference, 2020 NBER Insurance Group Meeting, Ninth BIS CCA Research Conference, and 2019 University of Kentucky Finance Conference for their many valuable comments and suggestions.

*** Banco Central do Brasil, Setor Bancario Sul Q.3 BL B - Asa Sul, Brasilia DF 70074-900, bernardus.doornik@bcb.gov.br

*** National University of Singapore, Mochtar Riady Building, Singapore 119245, dimasfazio@ nus.edu.sg

***** Princeton University, Julis Romo Rabinowitz Building, Princeton NJ 08544, schoenherr@ princeton.edu

******Washington University in St. Louis, One Brookings Drive, St. Louis MO 63130, jskrastins@wustl.edu
} 


\section{Introduction}

Risk-taking in pursuit of profitable investment opportunities is a fundamental driver of economic growth (Acemoglu and Zilibotti, 1997; Levine and Zervos, 1998). It is often argued that individuals' risk aversion reduces corporate risk-taking and investment below their optimal levels (Acemoglu and Shimer, 1999). For example, risk aversion of managers and other employees may restrict firms' ability to engage in profitable but risky financing and investment strategies (Jensen and Meckling, 1976; Amihud and Lev, 1981; Smith and Stulz, 1985; Holmström, 1999; Murphy, 1999; Berk et al., 2010; Gormley and Matsa, 2016).

Firms can devise mechanisms to mitigate the impact of employees' risk preferences on firm value. For example, firms can design contracts to insure employees against income risk. However, such mechanisms are limited in terms of scope to insure employees against all business risk. In particular, firms cannot fully insure workers against unemployment risk, since layoffs often occur in states in which firms lack resources to compensate employees (Lamadon, 2014; Fagereng et al., 2017). Consistent with this view, employees demand a wage premium for exposure to unemployment risk (Abowd and Ashenfelter, 1981; Topel, 1984; Li, 1986; Rosen, 1986; Hamermesh and Wolfe, 1990; Peters and Wagner, 2014), which is akin to a tax on corporate activities that increase unemployment risk.

In this paper, we assess whether a policy externality of unemployment insurance (UI) is to increase workers' tolerance for corporate risk-taking and thereby increase labor supply to riskier firms (Acemoglu and Shimer, 1999). We find that a more generous UI system reallocates labor supply toward riskier firms and reduces the compensating wage differential risky firms need to pay. In addition, a more generous UI system encourages entrepreneurship by reducing new firms' labor costs. Combined with evidence that a reduction in UI generosity reduces risky firms' value, these results suggest that UI acts as a subsidy to risky firms by lowering their labor costs.

Detecting how changes in UI reallocate labor supply in the economy is beset by challenges. Most notably, firm characteristics and the design of UI systems are endogenous and may correlate with confounding factors that affect cross-sectional and time-series variation in employment and wages. For example, UI duration is often extended during recessions. Also, differences in employment and wages are jointly determined by the supply of and demand for labor, which are difficult to disentangle in the data.

To overcome these challenges, we exploit a sudden and unexpected UI reform in Brazil in 2015 that tightened eligibility criteria for about 60 percent of workers. Prior to the reform, all laid-off workers were eligible for UI benefits if they had been employed for at least 6 consecutive months prior to layoff. The reform tightened eligibility criteria for 
workers with fewer than two previous UI benefits spells. Specifically, after the reform, first (second) time applicants for UI benefits require formal employment for at least 18 (12) out of the previous 24 (16) months to qualify (see Figure 1). Eligibility criteria remained unchanged for workers with at least two previous UI benefits spells.

In our empirical analysis, we compare changes in labor supply for risky and safe firms in response to a tightening of UI eligibility criteria. Since firms employ both workers affected and workers unaffected by the reform, we can compare changes in labor supply for affected and unaffected workers within the same firm for safe and risky firms. This triple-difference estimation with unaffected workers as a control group allows us to control for firm-time fixed effects, which rules out confounding factors related to firm-level changes in labor supply and demand.

We observe a reduction in labor supply for workers whose eligibility criteria for UI are tightened by the reform. In our strictest specification, in which we compare workers around the threshold at which the reform applies (one vs. two prior UI benefits spells), we find that employment drops by 2.18 percent and wages increase by 0.52 percent for workers whose eligibility criteria are tightened relative to workers unaffected by the reform. Similarly, hiring rates of workers affected by the reform decline by 0.34 ppt per month and hiring wages increase by 1.34 percent relative to workers unaffected by the reform.

Comparing changes in labor supply for risky and safe firms, we observe a relative decline in employment of workers affected by the reform by 0.24 to $0.48 \mathrm{ppt}$ and a relative increase in wages by 0.08 to 0.18 ppt per risk decile. ${ }^{1}$ We find the same patterns for hiring rates and wages. Further, consistent with a reallocation of labor supply from riskier to safer firms, we observe that workers affected by the reform become more likely to transition from riskier to safer firms after the reform when UI is less generous.

The surprise announcement of the UI reform allows us to quantify the value of UI for risky relative to safe firms in an event study. In the 5 days around the announcement of the reform, firms with above-median levels of risk experience 1.2-2.3 percent lower returns than safe firms in line with the estimated increase in labor costs for risky firms. This suggests that a more generous UI system benefits risky relative to safe firms.

We complement our analysis with a set of robustness tests that strengthen the interpretation of our findings. Our triple-difference estimation implies that any confounding factor would not only have to differentially affect the labor supply of workers affected and workers unaffected by the reform, but this difference would also have to vary with firm risk. In addition, any alternative explanation would need to account for the sharp response of employment and wages after the announcement of the reform.

First, to allay concerns that workers with more UI spells differ in terms of characteristics

\footnotetext{
${ }^{1}$ We measure firm-level unemployment risk through layoff intensities and credit risk.
} 
that affect their labor supply around the reform, we compare changes in labor supply for workers around the one vs. two prior UI spells threshold to changes in labor supply for workers around adjacent thresholds (two vs. three, three vs. four spells). We find that labor supply of workers with one additional UI benefits spell does not decline for risky relative to safe firms after the reform except at the threshold at which the reform applies.

Second, we assess whether macroeconomic shocks affect our results. During our sample period, Brazil experienced a recession that deepened after the reform. To explain our results, employment and wages of workers affected and unaffected by the reform would have to change differently in response to macroeconomic shocks. These differentials would also have to vary with firm risk. Differences in labor demand for affected and unaffected workers during recessions cannot explain our results, since demand effects would imply that employment and wages change in the same direction. To directly assess whether affected workers' labor supply changes differentially in response to recessions, we examine changes in employment and wages for both groups of workers around the period during which the Brazilian economy was affected by the global financial crisis in 2008. We find that neither employment nor wages responds differently for workers affected and workers unaffected by the reform in safe and risky firms. This suggests that the labor supply of workers affected and workers unaffected by the reform does not differently change for safe and risky firms during recessions.

Third, we ensure that our results are not affected by changes in the composition of workers around the reform. By replicating our wage analysis at the individual worker level, we are able to control for worker fixed effects. We find qualitatively and quantitatively identical results, which suggests that our results are not affected by changes in the composition of workers for riskier and safer firms.

Fourth, to ensure that our results are not affected by firm characteristics correlated with unemployment risk, we instrument for layoff risk based on links to suppliers exposed to adverse weather shocks. Fazio, Silva, and Skrastins (2019) document that customers linked to suppliers exposed to a weather shock experience a drop in cash flows and employment of 13 and 6 percent, respectively. We confirm that weather shocks affect layoff risk in the long term. We find qualitatively identical results using this instrumental variable strategy.

Finally, our results are robust to defining layoff risk at the firm-occupation level, controlling for workers' wage growth profiles, and are present in areas with above- and below-median levels of labor market informality.

In the second part of the paper, we examine whether UI generosity has real implications for risk-taking. We focus on changes in entrepreneurship, which is an inherently risky endeavor and easier to measure than changes in corporate risk-taking.

We find that making it harder for workers to qualify for UI benefits reduces new business creation. First, a simple entitlement effect suggests that individuals for whom it 
becomes harder to qualify for benefits are more likely to start a new business when formal employment becomes less attractive (Hamermesh 1979). Consistent with this conjecture, we find that workers affected by the reform become 3.38 percent more likely to start a new business relative to workers unaffected by the reform. Second, since the reform increases risky firms' labor costs, starting a new business becomes less profitable. Accordingly, we find that individuals are 1.21 percent less likely to start a new business per 10 ppt increase in the share of workers experiencing a reduction in UI benefits in a given municipality. Lower rates of business creation in municipalities with a larger share of affected workers suggest that the labor cost channel dominates the entitlement effect. Finally, we find that the average quality of new businesses increases after the reform, suggesting that tightening access to UI benefits discourages the creation of marginal firms.

Together, our results suggest that a more generous UI system reallocates labor supply from safe to risky firms, enabling risky firms to attract workers with lower wages. Lower labor costs increase risky firms' value and encourage new business formation. Thus, UI acts as a subsidy to risky firms' labor costs and encourages risk-taking in the economy consistent with Acemoglu and Shimer (1999), who argue theoretically that UI increases workers' willingness to accept more productive but riskier jobs. Since UI systems are typically financed through taxes on labor, they constitute a transfer system from safer to riskier firms.

While some recent empirical studies provide evidence consistent with a link between firm-level unemployment risk and labor supply, evidence on equilibrium employment and wages and their interaction with UI generosity is scant. Exploiting data on job applications, Brown and Matsa (2016) show that higher perceived firm risk is associated with fewer applications. Baghai et al. (2019) document that skilled workers depart distressed firms at a higher rate. Finally, Agrawal and Matsa (2013) show that firms pursue safer financing strategies when workers' UI protection is weaker. One possible explanation for this finding could be that workers are less sensitive to firm risk when UI is more generous.

However, Jaeger et al. (forthcoming) provide empirical evidence inconsistent with this conjecture showing that wages are inelastic with respect to variation in UI generosity. Additionally, due to the endogeneity of firm-worker matches it is unclear whether changes in UI generosity benefit risky firms more than safe firms. If the most risk-averse workers select into the safest firms and the least risk-averse workers select into the riskiest firms, workers in safer firms may be more sensitive to changes in the generosity of UI than workers in riskier firms.

Our unique setting allows us to shed light on the mixed empirical evidence by jointly examining the interaction between firm risk, wages, and UI. Our findings suggest that workers are sensitive to both the unemployment risk they are exposed to through their employer and to access to UI protection. Labor supply relatively declines for riskier firms 
when it becomes harder for workers to qualify for UI benefits.

Faced with a reduction in labor supply, how risky firms adjust employment and wages depends on their labor demand elasticity. ${ }^{2}$ Our results suggest that firms adjust both margins. They pay higher wages when workers demand higher compensation for unemployment risk, but are unwilling to fully compensate all workers and instead accept a drop in employment.

At first glance, our results seem to contradict the evidence in Jaeger et al. (forthcoming). However, the studies differ in one important dimension. While Jaeger et al. (forthcoming) examine wage elasticities in response to changes in the level of UI benefits (intensive margin), we examine variation in the probability of qualifying for UI benefits (extensive margin). The difference between our findings suggest that wages are more sensitive to variation in access to UI benefits than to their level, which hints at a non-linear relationship between UI protection and wages. Workers with a concave utility function value the first dollar of insurance more highly than an increase in UI benefits at a higher level, in particular in the context of an already generous UI system as in Jaeger et al. (forthcoming).

Changes in workers' sensitivity to risk have direct implications for corporate risktaking. Prior literature shows that risk-averse CEOs alter firms' financing and investment policies to reduce risk (Jensen and Meckling, 1976; Amihud and Lev, 1981; Tufano, 1996; Gormley and Matsa, 2016; Schoenherr and Starmans, 2019). Our analysis shows that UI programs play an important role in reducing workers' sensitivity to unemployment risk, which allows firms to engage in riskier financing and investment strategies.

We document that one channel through which workers' sensitivity to unemployment risk affects risk-taking in the economy is entrepreneurship. Hombert et al. (2020) show that providing UI directly to business owners affects their propensity to start a new business. We document two novel channels through which providing UI to employees rather than the owner of the business affects entrepreneurship. First, the provision of UI crowds out entrepreneurship through an entitlement effect that makes formal employment relatively more attractive. Second, UI reduces the labor costs of new businesses, which in turn makes starting a new business more profitable and spurs entrepreneurship. We find that the labor cost effect dominates, leading to a positive relationship between UI provision and entrepreneurship.

Our findings also provide novel insights into the literature on optimal UI design. The standard Baily-Chetty framework characterizes the optimal policy choice as a trade-off between the adverse effects of UI on labor supply and welfare gains from protecting individuals against income shocks. Some recent studies show that UI has additional important implications. For instance, Hsu, Matsa, and Melzer (2018) document that UI acts as a housing market stabilizer, Kuka (forthcoming) argues that access to UI improves

\footnotetext{
${ }^{2}$ It is possible that lower job application rates have no detectable effect if labor supply is abundant.
} 
health outcomes, and Barr and Turner (2015) argue that UI programs affect post secondary enrollment choices. Our findings suggest that UI creates a transfer system in which safe firms subsidize risky firms' labor costs, and therefore subsidizes corporate risk-taking.

\section{Institutional Background and Data}

This section provides information about the UI system in Brazil and describes the UI reform implemented in March 2015 and the data used for our empirical analysis.

\subsection{Unemployment Insurance in Brazil}

In Brazil, every formal worker holds a working card, which employers are required to sign whenever a worker is hired, promoted, or dismissed. This information is reported to the Ministry of Economics every year. Formal employees are entitled to a minimum wage. Payroll taxes amount to 20 percent of the formal wage to finance the public pension system, plus 8.5 percent for the worker's seniority account (FGTS). All formal employees in the private sector participate in the UI system. Funding for the UI system comes from the social integration program (PIS), which is mainly financed through a 0.65 percent tax on annual firm sales.

To be eligible for UI benefits, workers cannot simply quit, but need to be laid off by their employer. UI benefits are paid for 3 to 5 months, depending on the worker's time in formal employment. Three payments are made if a worker was employed between 6 and 11 months in the last 36 months, four payments are made if a worker was employed between 12 and 23 months in the last 36 months, and five payments are made if a worker was employed for at least 24 months in the last 36 months. In 2015, the monthly payment ranged from 1 to 1.76 minimum salaries, depending on the average pre-layoff wage. The UI system does not feature a direct experience rating mechanism. If a firm lays off a worker without a justified reason, it must pay an additional 50 percent of the total contribution that has accumulated in the employee's FGTS. This cost of laying off a worker amounts to 8-19 percent of the expected benefits payments to the worker, depending on the pre-layoff wage. 80 percent of the penalty is directly paid to the worker, and 20 percent goes towards funding the UI system. Firing workers with a valid legal justification does not involve penalties, and fired workers do not qualify for UI. However, firings are rare (3.5 percent of all dismissals), since the burden of providing evidence is high and judges tend to rule in favor of employees. 


\subsection{Unemployment Insurance Reform}

To be eligible for UI benefits prior to March 1, 2015, a worker had to be employed over a consecutive period of at least 6 months prior to layoff, may not earn other labor income, and may not have successfully applied for UI benefits during the previous 16 months. On December 29, 2014, the parliament announced a provisional measure that tightened eligibility criteria for UI benefits. This provisional measure was formally enacted the next day. The new criteria were set to be enforced from March 1, 2015. Both the sudden implementation and the content of the new law were unexpected. ${ }^{3}$ The main driver for the quick implementation and the tightening in eligibility criteria was attempts on the government's part to reduce the growing budget deficit. The size and duration of UI benefits were not altered. Importantly, employers' UI contributions were unaffected by the reform. Thus, the reform had no direct effect on employers' demand for formal labor.

The reform affected about 60 percent of workers. These were workers with less than two successful prior applications for UI benefits. For these workers, eligibility criteria were tightened. To be eligible for UI benefits after the reform, a longer employment history was required. Specifically, workers who were applying for the first time required documented employment of at least 18 months during the 24 months prior to layoff. Workers who were applying for the second time required 12 months of formal employment during the last 16 months (see Figure 1). The provisional measure was applied from March 2015 and became law in July 2015 with some adjustments. The adjusted requirements from July 2015 required that a first-time applicant have at least 12 months of employment in the last 18 months. A second-time applicant had to have at least 9 months of employment in the last 12 months.

To estimate the effect of the reform on the average worker, we compute the reduction in expected UI benefits. Before the reform, the probability of being laid off with a tenure of 6 to 17 months (which no longer qualifies workers for UI benefits after the reform) is 0.1549 . Given that the average worker qualifies for 4.51 months of UI benefits with a replacement rate of 0.6661 , this means that the drop in expected UI benefits amounts to $0.1549 * 4.51 * 0.6661=0.4653$ monthly wages. For workers whose eligibility criteria change from 6 to 12 months, the equivalent value is 0.2863 monthly wages based on a 0.0953 probability of being laid off with a tenure between 6 and 11 months. For the adjusted eligibility criteria from July 2015 that required workers with one previous UI spell to be employed for 9 months, the expected drop in UI benefits is 0.1595 monthly wages, based on an expected layoff probability of 0.0531 with a tenure of 6 to 8 months. In our empirical analysis, we relate these values to observed changes in wages and firm value.

3Estadao Politica, December 29, 2014, "Força Sindical nega ter sido consultada sobre ajuste em benefícios." 


\subsection{Data}

Our main data on employment and wage measures are from RAIS (Relação Anual de Informações Sociais), a large restricted-access matched employee-employer administrative data set from Brazil. The RAIS database records information on all formally employed workers and is maintained by the Ministry of Economics. All firms in Brazil are legally required to report annual information on each worker the firm employs. RAIS includes detailed information on the employer (tax number, sector of activity, establishment size, geographical location), the employee (social security number, age, gender, education), and the employment relationship (wage, tenure, type of employment, hiring date, layoff date, reason for layoff, etc.). We use data from RAIS for the period 2013-2016. In a given year, RAIS covers about 50 million formal employees.

The median firm in RAIS has three employees. For these firms, it is not possible to compute the risk measures that are central to our analysis. Additionally, in our sharpest specification, we require that firms employ or hire workers with exactly one and exactly two prior UI benefits spells within the same occupation or age group. To satisfy these requirements, we restrict our sample to firms with 100 or more workers, which are classified as large firms in Brazil. For these firms, we are able to compute firm risk measures and explore the cross-sectional variation in employees required for our analysis (see Section 4 for details).

We combine data from RAIS with information on the number of previous unemployment spells with UI benefits payments maintained by the Ministry of Economics. This information is crucial, as the reform only applies to workers with fewer than two past UI benefits spells. We exclude public sector employees, since they do not participate in the UI program. In addition, we use information on the location of firms (municipality), firms' two-digit industry classification (National Classification of Economic Activities), and information on workers' occupations (Classificação Brasileira de Ocupaçõ).

For our analysis, we need to classify firms according to the unemployment risk their workers are exposed to. We compute three proxies of firm risk. The first proxy directly captures layoff risk. For each firm, we compute the probability of a newly hired worker being laid off within 12 months during the pre-reform period from 2013 to 2014. For our other proxies, we obtain information on all outstanding corporate loans recorded by SCR (Sistema de Informações de Crédito do Banco Central), a restricted-access credit registry managed by the Central Bank of Brazil (BCB). This provides us with market-based proxies for firm risk through credit spreads and provisions on loans that banks have to hold with the $\mathrm{BCB}$ based on the assessed risk of a given borrower.

For our instrumental variable strategy, we rely on information about firms' suppliers, which we identify using transaction-level data from the Brazilian Payment Systems (the 
Sistema de Transferência de Reservas (STR) and Sistema de Transferência de Fundos (CIP-Sitraf)). We classify firms as suppliers based on the direction of observed money transfers.

We also use two data sets from the Brazilian IRS (Receita Federal). One data set covers information about all formal businesses in Brazil (Cadastro Nacional de Pessoas Jurídicas), from which we extract information on ownership and opening and closing dates. ${ }^{4}$ The other data set, the population registry of Brazil (Cadastro de Pessoas Físicas), provides information on individuals' residence.

\section{Hypothesis Development}

This section provides a simple model to illustrate the main effects of the UI reform in Brazil on labor supply, wages, firm value, and entrepreneurship. We use insights from the model to develop testable hypotheses.

\subsection{Employment and Wages}

Suppose that in a given period, workers receive a formal job offer and are endowed with an outside option they can resort to if they reject the job offer - for example, an informal job or self-employment. Job offers consist of two parameters: layoff risk $\lambda$ associated with the firm making the offer and wage $w$. If workers accept the job offer, they earn the wage $w$ with probability $(1-\lambda)$ and are laid off with probability $\lambda$, in which case they receive UI benefit $B$. The level of UI benefits $B$ is a fraction of the previous wage, and thus $w>B$. If workers reject the job offer, they enjoy a utility of $v$ from their outside option. Thus, the condition for workers to accept a job offer is $(1-\lambda) w+\lambda B \geq v$, which implies that the reservation wage $w_{R}$, the lowest wage a worker is willing to accept, is given by $w_{R}=\frac{v-\lambda B}{(1-\lambda)}$.

The reservation wage for a worker is higher for firms with a higher level of layoff risk $\lambda$. Intuitively, an increase in $\lambda$ shifts probability from the higher income wage state to the lower income unemployment state, reducing the value of formal employment by $\lambda(w-B)$. This drop in the value of employment must be compensated for by a higher wage. ${ }^{5} \mathrm{~A}$ higher level of UI benefits reduces the worker's reservation wage by increasing the value of formal employment.

The main effect of the UI reform is to reduce the probability of qualifying for UI for a subset of workers. Thus, for these workers the expected value of UI benefits is lower: $\beta B$, with $\beta<1$. This changes workers' reservation wage to $w_{R}^{\prime}=\frac{v-\lambda \beta B}{(1-\lambda)}>\frac{v-\lambda B}{(1-\lambda)}=w_{R}$.

\footnotetext{
${ }^{4}$ The Recita Federal lists the legal representative of a company, typically its CEO. For newly formed firms, which we examine in our analysis, the founder is the legal representative in virtually all cases.

${ }^{5}$ We assume that workers are risk-neutral. If workers were risk averse, the wage differential for unemployment risk would be larger.
} 
The difference in the new and old reservation wage for workers affected by the reform is $\frac{(1-\beta) \lambda B}{(1-\lambda)}$. From this, it follows that the reservation wage increases more the lower the probability of qualifying for UI benefits $(\beta)$. Also, the difference is increasing in $\lambda$. Thus, the reservation wage for workers affected by the UI reform increases with layoff risk. Intuitively, for firms with higher layoff risk, workers are more likely to experience unemployment states and are therefore more sensitive to the reduction in expected UI benefits payments.

These insights imply two testable implications:

Hypothesis 1 (H1): Workers are less likely to accept formal employment and demand higher wages after the reform, when it is harder to qualify for UI benefits.

Hypothesis 2 (H2): Firms with higher layoff risk are more affected by lower labor supply and higher wage demands after the reform, when it is harder to qualify for UI benefits.

\subsection{Firm Value}

Our model can be extended to illustrate the effect of reduced access to UI on firm value and entrepreneurship. A firm's profits $\pi$ can be described as the difference between the revenues generated from its output and the cost of its inputs: $\pi=f(K, L) P-r K-w L$, where $f(K, L)$ denotes the firm's output, $P$ is the price of its output, and $K$ and $L$ are the input capital and labor, respectively. The variables $r$ and $w$ denote the cost of capital and labor. As discussed above, the cost of labor $w=\frac{v-\lambda B}{(1-\lambda)}$ is a negative function of expected UI benefits payments conditional on layoff. Thus, a drop in expected UI benefits that leads to an increase in wages reduces firms' profitability. The importance of this effect is positively correlated with the riskiness of the firm $(\lambda)$, which implies that the UI reform, which reduces access to UI for some workers, has a more negative effect on profits and hence on firm value for riskier firms:

Hypothesis 3 (H3): The value of risky firms relatively declines following the announcement of the reform that tightens UI eligibility criteria.

\subsection{Entrepreneurship}

Marginal individuals who decide to either start their own business or seek formal employment trade off the expected returns from entrepreneurship and formal employment. Thus, the conditions for starting a new business before and after the UI reform can be described 


$$
\begin{gathered}
\text { pre-reform : } f(K, L) P-r K-\frac{v-\lambda B}{(1-\lambda)} L \geq(1-\lambda) w+\lambda B, \\
\text { post }- \text { reform } \text { affected }: f(K, L) P-r K-\frac{v-\lambda \beta B}{(1-\lambda)} L \geq(1-\lambda) w+\lambda \beta B, \\
\text { post-reform } \text { unaffected }_{\text {ref }} f(K, L) P-r K-\frac{v-\lambda \beta B}{(1-\lambda)} L \geq(1-\lambda) w+\lambda B,
\end{gathered}
$$

where (1) describes the inequality for all workers before the reform and (2) and (3) describe the inequality for workers affected and unaffected by the reform, respectively.

As is evident from comparing equations (1) and (2), the UI reform has two effects on individuals' decision to start a new business. First, reducing the expected value of UI benefits by a factor $\beta<1$ makes formal employment less valuable for individuals affected by the reform, which implies an increase in entrepreneurship. Second, running a new business with employees is less profitable due to the higher wages that workers demand after the reform, in particular for high-risk firms, such as new businesses. ${ }^{6}$ This implies that fewer businesses are created after the reform. For individuals unaffected by the reform, only the profitability effect is relevant (equation (3)), which suggests that these individuals become less likely to start a new business after the reform. The insights from equations (1) to (3) provide us with two testable implications:

Hypothesis 4 (H4): Workers for whom it is harder to qualify for UI benefits through formal employment after the reform are relatively more likely to start a new business.

Hypothesis 5 (H5): Higher labor costs discourage the creation of new businesses after the reform.

Our framework allows us to consider which types of new businesses are generated or disappear after the reform. Individuals for whom formal employment becomes relatively less attractive due to the reform would have started a highly profitable business even before the reform when formal employment was more valuable. Thus, the additional new businesses created by workers for whom formal employment becomes less attractive are those for which expected profits are relatively lower. This suggests that

Hypothesis 6 (H6): The quality of businesses created by workers for whom it becomes harder to qualify for UI benefits relatively declines after the reform.

Examining equation (3) suggests that the firms that are not created due to higher labor costs are those that would barely have been profitable at pre-reform levels of labor

\footnotetext{
${ }^{6}$ The average wage firms would be required to pay after the reform is a weighted average of the wage of affected and unaffected workers. For notational convenience, we set the post-reform wage equal to the wage of affected workers. This does not affect the qualitative insights.
} 
costs, and therefore are no longer profitable under higher labor costs after the reform. However, at the same time labor costs increase for all new businesses that hire workers, thus reducing their profitability. Due to these opposing channels - positive selection and negative profitability effects - the overall change in the profitability of new businesses is ambiguous and depends on the relative strength of the two channels.

\section{Empirical Analysis}

In this section, we present our empirical analysis to test the hypotheses developed in the previous section, assessing the impact of UI on employment, wages, firm value, and entrepreneurship.

\subsection{Descriptive Statistics}

Before discussing our empirical strategy and results, we present descriptive statistics. In Table 1, Panel A, we report descriptive statistics separately for workers affected and workers unaffected by the reform. The last column shows the difference between the groups. All values are based on December 2014, the month in which the UI reform was announced.

Workers affected by the reform account for 69.36 percent of workers in the sample. The difference in wages between workers affected and unaffected by the reform is BRL 27 and not statistically significant. Similarly, wages for newly hired workers are almost identical. We do not observe significant differences in workers' education or the industries in which they are employed. Workers affected by the reform are 4.8 years younger, have 3.6 months longer tenure at their current job, and are 3 percent more likely to work in skilled occupations. We ensure that our analysis is not affected by these differences in our empirical design and additional robustness tests.

Panel B reports descriptive statistics for the firm-level measures that proxy for unemployment risk: the layoff rate within 12 months of hiring, the spread on debt obligations, and the default provisions banks are required to hold at the BCB on a firm's debt. On average, firms lay off 18 percent of workers within 12 months of hiring. The highest spread a firm pays on its debt is 120 percent on average, and banks on average hold 8 percent of the outstanding debt with the BCB in default provisions.

\subsection{Employment and Wages}

We begin our analysis by examining the relationship between access to UI and labor supply and its differential effect on safe and risky firms by testing Hypotheses (1) and (2). 


\subsubsection{Basic Reform Effect}

To examine whether workers reduce their formal labor supply when it becomes harder to qualify for UI benefits, we compare changes in employment and wages for workers who face tighter eligibility criteria after the reform and workers who are unaffected by the reform.

Hypothesis (1) predicts that employment declines and wages increase for workers affected by the reform. We start by depicting the time series of employment (top left panel) and wages (top right panel) in Figure 2 for workers affected (solid lines) and workers unaffected by the reform (dashed lines). ${ }^{7}$ While employment for both groups of workers follows parallel trends before the reform, employment of workers affected by the reform sharply drops from the first month after the announcement of the reform. Similarly, the wages of affected workers relatively increase from the month after the announcement of the reform. ${ }^{8}$ The same trends are present for hiring rates and hiring wages (bottom panels). Together, the trends in employment and wages are in line with a reduction in formal labor supply for workers affected by the reform, consistent with Hypothesis (1).

We confirm the insights from the graphical analysis statistically by estimating

$$
\text { ERate }_{i j, a g e, t}=\alpha_{i t}+\alpha_{i j}+\alpha_{\text {age }, t}+\beta \cdot \text { Affected }_{j} * \text { Reform }_{t}+\epsilon_{i j, a g e, t},
$$

where subscript $i$ denotes firms, $j$ denotes worker groups (affected vs. unaffected workers), and $t$ denotes time in months. Since we are interested in firm-level outcomes, we aggregate outcomes for both affected and unaffected workers at the firm level. This captures net changes in firm-level employment taking into account employment separations and hirings. In addition, as workers affected by the reform tend to be younger, we group workers in age groups and saturate equation (4) with age group-month fixed effects $\alpha_{\text {age,t }}{ }^{9}$ Thus, in a given month we compute the average outcome for each firm and worker-age group separately for workers affected and workers unaffected by the reform. ERate Rj,age,t $_{\text {a }}$ measures employment normalized by firm $i$ 's employment in the month before the an-

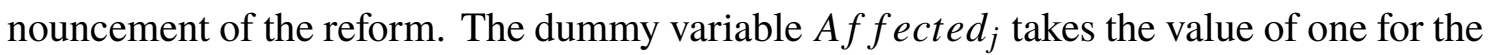
group of workers affected by the reform and zero for workers unaffected by the reform. The dummy variable Reform $t$ takes the value of one for the post-reform period in 2015 and 2016 and zero for the pre-reform period in 2013 and 2014.

Our empirical setting allows us to include firm-time fixed effects $\left(\alpha_{i t}\right)$. This eliminates concerns about time-varying confounding factors that may affect labor supply, labor demand, or wages at the firm level (e.g., macroeconomic shocks, productivity shocks).

\footnotetext{
${ }^{7}$ All plots are adjusted for calendar month-worker group fixed effects to control for seasonal effects.

${ }^{8}$ In Brazil, firms are free to engage in bilateral negotiations with workers, provided wages remain above the level agreed on in collective bargaining. This allows for variation in wages at the individual level.

${ }^{9}$ We split workers into six age groups: below 20, 20-29, 30-39, 40-49, 50-59, 60 and above.
} 
Thus, the variation we exploit stems from differential changes in employment and wages for workers affected and workers unaffected by the reform within the same firm and month and in the same age group, captured by $\beta$. We also include firm-worker group fixed effects $\left(\alpha_{i j}\right)$ to ensure that we track changes in employment and wages for the same firm-worker group pair over time.

The results are reported in Table 2, Panel A. We find that employment relatively decreases by about 6 percent for workers affected by the reform (column I). On examining changes in wages, we find that wages of workers affected by the reform relatively increase by 0.90 percent (column II). We observe similar effects for hired workers with a 0.52 percent relative decrease in monthly hiring rates scaled by total firm employment for workers affected by the reform (column III), and a 2.52 percent relative increase in hiring wages (column IV).

To mitigate concerns about differences in characteristics of workers affected and unaffected by the reform, in Panel B we restrict our sample to workers around the threshold at which the reform applies. Specifically, we compare workers with exactly one previous unemployment spell who are affected by the reform and workers with exactly two previous UI benefits spells who are not affected by the reform. We find qualitatively identical effects as for the full sample. Magnitudes around the threshold are about half as large as for the full sample. The difference in magnitudes is driven by the fact that the drop in expected UI benefits is about half as large for workers with one prior UI spell compared with workers with no prior UI spells, which implies that the effect of the reform is only half as strong for workers with exactly one prior UI benefits spell (see Section 2.2).

\subsubsection{Firm Risk}

We next turn to testing Hypothesis (2), which predicts that the labor supply of affected workers declines more for riskier firms after the reform. ${ }^{10}$ Figure 3 illustrates our main results graphically. We plot time series changes in employment (top left panel), wages (top right panel), hiring (bottom left panel), and hiring wages (bottom right panel) separately for firms in the highest risk quartile (solid lines) and firms in the lower risk quartile (dashed lines). ${ }^{11}$ Each line already takes the first difference in outcomes for workers affected and workers unaffected by the reform. The flat lines before the reform provide evidence that the parallel trend assumption is satisfied for both safe and risky firms. The decline in employment and hiring, as well as the increase in wages after the reform correspond to difference in patterns for workers affected and workers unaffected by the

\footnotetext{
${ }^{10} \mathrm{~A}$ necessary condition for workers to be sensitive to firm risk is that they perceive it. Brown and Matsa (2016) provide survey evidence that workers' perception of the riskiness of firms is strongly correlated with various measures of financial health.

${ }^{11}$ While these graphs are based on the credit risk measure, we observe the same patterns for all risk proxies.
} 
reform documented in Figure 2.

The main new insight from Figure 3 is the second difference showing that the drop in labor supply of workers affected by the reform is stronger for risky than for safe firms. For example, the top left plot shows that while employment of workers affected by the reform decreases relative to employment of workers unaffected by the reform for all firms, the relative decline is stronger for risky firms. Altogether, the plots provide evidence of a stronger decline in employment and increase in wages for workers affected by the reform in risky firms sharply after the reform.

We confirm the patterns from the graphical analysis by estimating

$$
\begin{aligned}
\text { ERate }_{i j, a g e, t}= & +\alpha_{i t}+\alpha_{i j}+\alpha_{\text {age }, t}+\beta \cdot \text { Affected }_{j} * \text { Reform }_{t} \\
& +\delta \cdot \text { Risk }_{i} * \text { Affected }_{j} * \text { Reform }_{t}+\epsilon_{i j, \text { age }, t} .
\end{aligned}
$$

Since workers are unlikely to track the exact value of risk measures, and instead have a broad sense of a firm's conditions, Risk $k_{i}$ splits firms into deciles according to each of the proxies of firm risk (see Section 4.1).

The results are displayed in Table 3, Panel A. We observe that employment of workers affected by the reform decreases by 27 to 67 basis points per risk decile relative to workers unaffected by the reform (odd columns). Wages for workers affected by the reform relatively increase by 6 to 29 basis points per risk decile after the reform (even columns). The results are robust to focusing on workers around the threshold at which the reform applies in Panel B.

Risky firms are not compensating the drop in employment of workers affected by the reform by employing more workers unaffected by the reform. In Table A.1, we show that total employment at risky firms drops in accordance with the reduction in labor supply of workers affected by the reform. For example, the 0.31 percent relative decline in employment for high credit spread firms after the reform is consistent with the drop in employment of workers affected by the reform. Employment of workers affected by the reform declines 0.27 percent more than for workers unaffected by the reform (Table 3, column I). Thus, the relative change in employment of workers unaffected by the reform $x$ can be computed from $(\mathrm{x}+(\mathrm{x}-0.0027))=-0.0031$, which yields $\mathrm{x}=0.02$. This means that employment of workers unaffected by the reform in risky firms remains stable after the reform with a 0.02 ppt decline per risk decile compared to a 0.27 ppt decline for affected workers. ${ }^{12}$

In Table 4 we examine relative changes in hiring and hiring wages for safe and risky firms around the reform. After the reform, monthly hiring of workers affected by the

\footnotetext{
${ }^{12}$ The relative employment changes of affected and unaffected workers in safe and risky firms are similar around the reform for all risk measures.
} 
reform declines by 0.01 to $0.02 \mathrm{ppt}$ (about 1 percent) relative to the existing workforce per risk decile (odd columns). Hiring wages of workers affected by the reform relatively increase by 0.09 to 0.16 percent per risk decile after the reform (even columns). The results are robust to focusing on workers around the threshold at which the reform applies in Panel B.

To provide additional insights into the reallocation of labor supply, we examine transitions of workers across firms. Specifically, we examine whether workers affected by the reform become more likely to transition from risker to safer firms by estimating

$$
\begin{aligned}
\Delta \text { Risk }_{i j, \text { age }, t}= & \alpha_{i t}+\alpha_{i j}+\alpha_{\text {age }, t}+\beta \cdot \text { Affected }_{j} * \text { Reform }_{t} \\
& +\rho \cdot \text { Affected }_{j} * \text { Reform }_{t} * \text { Risk }_{i}+\epsilon_{i j, \text { age }, t}
\end{aligned}
$$

where $\Delta R i s k_{i j, a g e, t}$ is the fraction of workers who transition to a safer firm after parting with firm $i$ in month $t$. The sample comprises all workers who experience separation from their employer during our sample period. $\alpha_{i t}$ denotes firm-month fixed effects, which ensures that the variation we exploit stems from workers separating from the same firm in the same month. All other variables are defined as before.

The results are shown in Table 5. We find that workers who become less likely to qualify for UI benefits after the reform become 0.29 to $0.34 \mathrm{ppt}$ more likely to transition to safer firms (odd columns). Interacting the independent variable in equation (6) with Risk, we find that workers become particularly more likely to transition to safer firms if they were previously employed at risky firms (even columns). This evidence on transitions at the worker level strengthens our interpretation of the results whereby a reduction in access to UI benefits leads to a reallocation of labor supply from riskier to safer firms.

Overall, the results in this section support Hypothesis (2), that reducing access to UI benefits reallocates formal labor supply from riskier to safer firms. ${ }^{13}$

\subsubsection{Pass-Through}

Next, we relate the observed changes in wages for workers affected by the reform to the expected drop in UI benefits. In Section 2.2, we calculate the expected reduction in UI benefits to be 0.2863 monthly wages for workers whose eligibility criteria change from 6 to 12 months of employment after the reform and 0.1595 monthly wages for workers whose eligibility criteria change from 6 to 9 months of employment. In the data, the expected employment duration is 13.24 months. Thus, if workers seek to be fully compensated for the expected loss in UI benefits over their expected employment period, they must demand $(0.2863 / 13.24=) 2.16$ percent or $(0.1595 / 13.24=) 1.20$ percent higher wages, respectively.

\footnotetext{
${ }^{13}$ Our wage results also imply that differential access to social security systems may lead to wage dispersion within the same firm for reasons other than productivity (Mueller et al. 2017).
} 
We compare these values to the observed changes in wages estimated in Table 2. Since 69.36 percent of the workers affected by the reform in our sample require 12 months of employment to qualify for UI benefits after the reform and 30.64 percent require 9 months of employment, the required increase in wages to offset the expected loss in UI benefits amounts to $(0.6936 * 0.0216+0.3064 * 0.0120)=0.0187$. The observed change in wages for newly hired workers is somewhat higher at 0.0252 (column IV, Panel A). Similarly, the change in hiring wages for workers with one previous UI spell, who require 9 months of employment to qualify for UI after the reform, is slightly higher at 1.34 percent (column IV, Panel B), than the required 1.20 percent to recover the expected loss in UI benefits. This suggests that fluctuations in UI protection fully pass through into equilibrium wages. If workers are risk averse, the pass-through can exceed one to one.

The probability of being laid off during the tenure range that no longer qualifies workers for UI benefits after the reform varies with firm risk. For example, the probability of being laid off with a tenure of 6 to 11 months is 0.0139 for the safest decile of firms, but 0.2128 for the riskiest decile of firms. When we update our estimates, adjusting for observed layoff probabilities, UI benefits duration, and replacement rates for workers in firms in different risk deciles, we get that workers with no prior UI benefits spells would require a 0.58 percent higher increase in wages per risk decile to be compensated for the additional expected loss in UI benefits in riskier firms after the reform $(0.35$ percent for workers with one previous UI benefits spell).

Our estimates in Table 4 allow us to assess whether these cross-sectional differences in unemployment risk at the firm level are reflected in differential wage responses to changes in eligibility rules for UI benefits. For the full sample, the required wage increase per risk decile after the reform to offset the additional unemployment risk at riskier firms is $(0.6936 * 0.58+0.3064 * 0.35)=0.51$ percent. Our estimate is somewhat lower, at 0.29 percent (column VI, Panel A). Similarly, for workers with one previous unemployment spell, the estimate of 0.18 percent (column VI, Panel B) is lower than the 0.35 percent that would be required to offset the additional expected loss in UI benefits per risk decile. This suggests that UI reduces the compensating wage differentials that firms are required to pay to workers to compensate them for higher layoff risk by about 51-57 cents per dollar in expected UI benefits. A possible explanation for the lower pass-through with respect to unemployment risk could be that workers underestimate the differences in unemployment risk across firms or workers with lower risk-aversion select into riskier firms making them less sensitive to variation in UI generosity.

\subsubsection{Robustness}

We next turn to strengthening the interpretation of our main results by assessing their robustness against potential alternative explanations. 
Prior UI Benefits Spells In our tightest specification, we compare workers with exactly one or two prior UI benefits spells. A potential concern with this analysis is that workers who experienced one more UI benefits spell differ from workers with one fewer UI benefits spell. To dispel such concerns, we compare changes in labor supply for workers with one additional UI benefits spell around the one-vs-two-spells threshold at which the reform applies and workers with one additional UI benefits spell around adjacent thresholds that are not affected by the reform (two vs. three and three vs. four spells). Specifically, we control for changes in labor supply for workers with one additional previous UI benefits spell by estimating

$$
\begin{aligned}
\text { ERate }_{i j, \text { age }, t}= & \alpha_{i t}+\alpha_{i j}+\beta_{1} \cdot \text { UPeriod }_{j} * \text { Reform }_{t}+\beta_{2} \cdot \text { Affected }_{j} * \text { Reform }_{t} \\
& +\beta_{3} \cdot \text { (7) } \text { UPeriod }_{j} * \text { Reform }_{t} * \text { Ris }_{i}+\beta_{4} \cdot \text { Affected }_{j} * \text { Reform }_{t} * \text { Risk }_{i} \\
& +\epsilon_{i j, \text { age }, t}
\end{aligned}
$$

for the sample of workers with one to four previous unemployment spells, where UPeriods $j$ measures the number of prior UI benefits spells. All other variables are defined as before.

The results are collected in Table 6, Panel A. Across all risk proxies, we find no evidence that an additional UI benefits spell is associated with lower labor supply to risky firms other than at the one-vs-two-prior-UI-spells threshold. If anything, an additional UI benefits spell at other thresholds is associated with higher employment of workers affected by the reform in riskier firms. Hence, controlling for the effects of an additional UI benefits spell on employment and wages does not affect the estimates for workers around the reform threshold. Put differently, to explain our results, differences in labor supply to risky and safe firms would need to differ between workers with exactly one and exactly two prior UI spells, but be the same for workers with exactly two, three, or four prior UI spells. It is hard to imagine a shock other than the UI reform that would only affect workers with one or two prior UI spells differentially, but has no differential effect for workers with two, three, or four prior UI spells.

Macroeconomic Conditions Next, we assess whether our results are affected by macroeconomic conditions. Brazil was in recession for most of our sample period. To affect the results, labor supply of workers affected and workers unaffected by the reform would have to react differentially to macroeconomic shocks. Differential labor demand effects cannot explain our results, since demand effects would imply that employment and wages change in the same direction. For example, if workers affected by the reform are more adversely affected by a recession, both their employment and wages should decline. In contrast, we observe that employment and wages change in opposite directions compared with workers unaffected by the reform.

From the outset, there is no clear reason why workers who received UI benefits one 
more time change their labor supply differentially in response to macroeconomic shocks and do so only for risky firms. To directly assess changes in labor supply of workers affected and workers unaffected by the reform in response to macroeconomic conditions, we turn to the last recession, when Brazil's economy was affected by the global financial crisis.

The results are gathered in Table 6, Panel B. We define the crisis period as the 9 months of negative growth from October 2008 to June 2009, and use a symmetric 9month window from January 2008 to September 2008 as the pre-crisis period. We do not observe a differential response of employment or wages for workers affected and unaffected by the UI reform for risky and safe firms. This suggests that labor supply to risky and safe firms does not differentially respond to macroeconomic shocks for workers affected and unaffected by the UI reform.

Worker Composition The composition of workers employed by risky and safe firms may change after the reform. In this case, changes in wages could be partially driven by changes in the composition of workers. To dispel this concern, we reestimate the wage tests at the individual worker level, which allows us to control for worker fixed effects. The results are shown in Table 7 . We find that the results are almost identical after controlling for worker fixed effects. ${ }^{14}$

Exogenous Variation in Firm Risk Risk is an endogenous firm characteristic that may be correlated with other characteristics that could differentially affect labor supply for workers who are exposed to different levels of UI protection.

To mitigate this concern, we instrument for layoff risk in equation (5) using exogenous weather shocks. ${ }^{15}$ Specifically, we instrument for layoff risk by links to suppliers that are exposed to adverse weather shocks during the pre-reform period by estimating

$$
\begin{aligned}
\widehat{\text { Risk }_{i}}= & \gamma_{1} \cdot \text { shock }_{i}+\gamma_{2} \cdot \text { exposure }_{i}+\gamma_{3} \cdot \text { shock size }_{i} \\
& +\gamma_{4} \cdot \log (\text { employees })_{i}+\epsilon_{i},
\end{aligned}
$$

where shock $_{i}$ is a dummy variable that takes the value of one if a supplier of firm $i$ experiences an adverse weather shock and zero otherwise, ${ }^{16}$ exposure $_{i}$ is the share of firm $i$ 's total payments going to shocked suppliers, shock size $e_{i}$ is the log of total damages

\footnotetext{
${ }^{14}$ Due to computational constraints, we extract a 10 percent random sample of workers.

${ }^{15}$ Severe weather shocks are defined as natural disasters that are declared an emergency by the federal government and cause at least BRL 100 million in damage. Data are provided by the Brazilian Integration Ministry. Fazio, Silva, and Skrastins (2019) document that being connected to suppliers hit by unexpected weather shocks reduces firms' cash flows by 11 percent and their employment by 6 percent.

${ }^{16}$ To identify firms connected to suppliers in the affected areas, we use inter-bank transfer data (STR), which records inter-bank payments between firms.
} 
caused by the natural disaster that affects firm $i$ 's suppliers, and $\log (\text { employees })_{i}$ is the $\log$ of firm $i$ 's employment.

The results are reported in Table A.2. The results in column I indicate that being connected to a supplier who experiences a natural disaster shifts firms up by 2.23 deciles in the distribution of layoff risk and by an additional 0.05 deciles per 10 ppt increase in the fraction of a firm's cash flows going to an affected supplier. After accounting for firm-specific exposure, the overall size of the damages in the area where the supplier is located has no positive effect on layoff risk. Finally, firm size has no effect on how layoff risk changes through connections to affected suppliers. On the one hand, larger firms are more likely to be affected because they rely on more suppliers. On the other hand, being connected to a larger number of suppliers renders them more diversified than smaller firms.

While we rely on the pre-reform period to predict layoff risk to steer clear of endogenous effects of the reform on firm risk, it is important for our strategy to be valid that shocks predict layoff risk in the long run. The results in column II confirm that this is the case. Being linked to a supplier that is subject to a natural disaster during the pre-reform period predicts higher layoff risk even during the post-reform period.

The results from the second stage are displayed in Table 8 . We find a 2.18 percent higher decline in employment (column I) and a 0.08 percent higher decline in hiring rates per risk decile for workers affected by the reform (column III). Wages and hiring wages of workers who are less likely to qualify for UI after the reform increase by 1.13 and 1.08 percent more per risk decile (columns II and IV), respectively. Observing qualitatively identical results relying on exogenous shocks to firms to proxy for firm risk mitigates concerns that the reduction in labor supply to risky firms after the reform may be driven by unobservable firm characteristics correlated with risk.

Estimates from the instrumental variable strategy are about three to four times larger for employment and wages, respectively, and about six to seven times larger for hiring rates and wages. Various factors could explain the difference in magnitudes. First, endogenous measures of firm risk based on layoff intensities and credit risk may be correlated with other firm characteristics that reduce workers' sensitivity to UI protection. Second, shocks to a firm's supplier are salient events that may be easier to gauge than other dimensions of firms' risk. Third, workers with higher risk tolerance may sort into riskier firms rendering them less sensitive to UI protection. Thus, workers of firms that experience an exogenous shock to risk might be more risk averse on average than workers of firms whose riskiness build up over time. 


\subsection{Firm Value}

Hypothesis (3) predicts that higher labor costs associated with a reduction in access to UI benefits for some workers after the reform lead to a relative drop in value for risky firms.

The surprise announcement of the reform allows us to estimate the relative effect of tightening eligibility criteria for UI on the value of safe and risky firms. We conduct a standard event study comparing cumulative abnormal returns of safe and risky listed firms in a five-trading-day window around the announcement of the reform on December 29, 2014 , by estimating ${ }^{17}$

$$
C A R_{i}=\alpha+\gamma \cdot \operatorname{Risk}_{i}+\epsilon_{i}
$$

where $C A R_{i}$ is the cumulative abnormal stock return of firm $i$ estimated using a market model (MacKinlay 1997) with the Brazilian stock market index (BOVESPA) as the benchmark. The variable Risk $k_{i}$ takes the value of one for firms with above-median levels of risk and zero for firms with below-median levels of risk.

Figure 4 depicts the distribution of cumulative abnormal returns of firms with above (solid lines) and below (dashed lines) median levels of credit spreads (left panel), default provisions (middle panel), and layoff risk (right panel) for the 5-day window around the announcement of the reform. There is a clear leftward shift in the return distribution for risky firms around the announcement of the UI reform for all risk proxies.

By measuring the magnitude of the effect in Table 9, we find that firms with abovemedian levels of risk experience a 1.19 to 2.38 percent higher decline in firm value than safe firms following the announcement of the reform. ${ }^{18}$ This suggests that the provision of UI has a differential impact on risky and safe firms. The generosity of the UI system acts as a subsidy to risky firms by reducing their labor costs, as documented in the previous section, consistent with the predictions of Hypothesis (3).

Next, we relate changes in firm value to changes in wages following the announcement of the UI reform. To calculate implied changes in firm value from changes in wages, we compute firm value as a multiple of earnings that the firm generates. In this case, changes in earnings are proportionally reflected in the value of the firm, i.e., a permanent drop in earnings by 1 percent reduces firm value by 1 percent.

Our estimates suggest that wages increase by 0.90 percent for workers affected by the UI reform. Since for listed firms 74.03 percent of workers are affected by the reform, their wage bill increases by $(0.0090 * 0.7403=) 0.67$ percent. Wages account for 59 percent

\footnotetext{
${ }^{17}$ The results are qualitatively identical for a 3-day window around December 29.

${ }^{18}$ Since many stocks are not frequently traded in Brazil, we depict the results for different thresholds of days a stock is traded in 2014 (50 days in columns I, IV, and VII, 100 days in columns II, V, and VIII, and 200 days in columns III, VI, and IX.)
} 
of listed firms' earnings in 2014 for the firms in our sample. This implies that a 0.67 percent increase in wages reduces earnings, and therefore firm value, by $(0.59 * 0.0067=)$ 0.40 percent.

Since we estimate the relative change in firm value for high-risk and low-risk firms, we need to compute the implied change in firm value separately for firms with aboveand below-median levels of risk. The average high-risk firm is five risk deciles above the average low-risk firm, which implies that wages for workers affected by the reform increase by $\left(5^{*} 0.0029=\right) 1.45$ percent more for risky firms, where risk is measured as layoff risk (Table 3, column VI). Multiplied by the fraction of workers affected by the reform, this means that risky firms' wage bill increases by $\left(0.0145^{*} 0.7403=\right) 1.07 \mathrm{ppt}$ more than for safe firms. Risky firms also feature lower earnings, with wages accounting for 123 percent of their earnings, compared with 55 percent for safe firms.

Taking into account the differences in earnings and the higher increase in wages, the high-risk firms' value drops by 1.27 percent more than for safe firms ([-0.0083+ $7.5 * 0.0029] * 0.7403 * 1.23=0.0122$ vs. $[-0.0083+2.5 * 0.0029] * 0.7403 * 0.55=-0.0004)$. This estimate falls in the range of estimated changes in firm value for risky firms documented in Table 9.19

\subsection{Entrepreneurship}

Finally, we examine the effect of changes in the generosity of UI on entrepreneurship by testing Hypotheses (4) to (6).

We start by depicting changes in business formation rates around the reform in Figure 5. In the top panel, we plot monthly business formation rates for workers affected (solid line) and workers unaffected (dashed line) by the reform. While we observe parallel trends in business formation rates before the reform, workers affected by the reform become more likely to start a new business from about 3 months after the reform, consistent with Hypothesis (4). In Panel B, we show business formation rates for municipalities with above-median (solid line) and below-median shares (dashed line) of workers affected by the reform (see Figure 6). ${ }^{20}$ While business formation rates evolve similarly before the reform, from about 3 months after the reform business formation rates relatively decline in municipalities with above-median levels of workers affected by the reform, consistent with Hypothesis (5).

To test Hypothesis (4) formally, we compare changes in the rate at which individuals

\footnotetext{
${ }^{19}$ For non-listed firms, we compute a relative drop in implied firm value for risky over safe firms of 1.99 percent.

${ }^{20}$ We measure the share of affected workers in the entire working-age population to capture all potential employees of new firms.
} 
start a new business for workers affected and unaffected by the reform by estimating

$$
\log \left(\text { business } \text { formation }_{j m t}=\alpha_{j m}+\alpha_{m t}+\mu \cdot \text { Affected }_{j} \cdot \text { Reform }_{t}+\epsilon_{j m t},\right.
$$

where $\log$ (business formation $)_{j m t}$ is the number of businesses established by affected or unaffected individuals $j$ in municipality $m$ in month $t$. Individual group-municipality fixed effects $\alpha_{j m}$ ensure that we track changes in entrepreneurship for the same group of individuals in the same municipality over time, and municipality-month fixed effects $\alpha_{m t}$ control for local shocks that may affect new business formation. All other variables are defined as before.

The results are collected in Table 10, Panel A, column I. We find that individuals affected by the reform start 3.38 percent more new businesses after the reform compared with individuals unaffected by the reform, consistent with Hypothesis (4).

Hypothesis (5) predicts that higher labor costs after the reform reduce the expected profits from starting a new business and reduce new business formation. To test this hypothesis, we cannot compare individuals affected and unaffected by the reform, since the higher labor costs of potential employees affect them equally. Instead, we replace

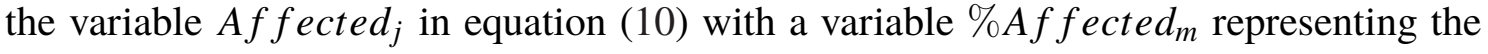
share of workers in a given municipality who are affected by the reform. To sharpen the identification, we control for mesoregion-time fixed effects, which ensures that we compare adjacent municipalities. ${ }^{21}$

The results are displayed in Panel B, column I. We find that business formation rates decline by $1.21 \mathrm{ppt}$ per $10 \mathrm{ppt}$ increase in the share of individuals in a given municipality who are affected by the reform, as predicted by Hypothesis (5).

Under Hypothesis (6), new businesses established by workers affected by the reform are of lower quality, which reduces the average quality of businesses. To measure the quality of newly established businesses, we use default rates and access to credit markets and replace the dependent variable in equation (10) with these measures.

The results are gathered in columns II to IV in Table 10, Panel A. Wages are similar for workers hired by firms started by workers affected and workers unaffected by the reform. We find evidence consistent with new businesses established by workers affected by the reform being less profitable than the average firm. The probability of a new business closing within 12 months relatively increases by $0.43 \mathrm{ppt}$ for businesses started by individuals affected by the reform (column III). These businesses are also $0.29 \mathrm{ppt}$ less likely to obtain credit financing (column IV).

Next, we examine whether higher labor costs affect the average quality of new busi-

\footnotetext{
${ }^{21} \mathrm{~A}$ mesoregion consists of about eight neighboring municipalities on average that are defined as being similar by the central statistics bureau (IBGE).
} 
nesses. On the one hand, higher labor costs may lead marginal and less profitable businesses to disappear, but on the other hand, higher labor costs render new businesses less profitable. To test which effect dominates in the data, we compare the quality of businesses established in municipalities in which more or fewer workers are affected by the reform. The results are shown in Table 10, Panel B. Consistent with labor costs increasing more in municipalities in which more workers are affected by the reform, we find that newly established firms have to pay 0.43 percent higher wages per $10 \mathrm{ppt}$ increase in the fraction of workers affected by the reform relative to their workers' previous wage (column II). Additionally, we observe that a ten ppt increase in workers affected by the reform in a given municipality is associated with a $0.38 \mathrm{ppt}$ decline in closures (column III) and a 0.42 ppt increase in access to credit (column IV). This suggests that the positive selection effect of higher expected labor costs driving out the establishment of marginal firms dominates the negative performance effect of higher wages.

Overall, the results in this section suggest that a more generous UI system encourages entrepreneurship, which leads to more businesses being created. This effect is particularly strong for marginal businesses that become unprofitable when labor costs increase.

\section{Additional Robustness Tests}

This section presents additional robustness tests to strengthen interpretation of the empirical results. Concerns about confounding factors correlated with firm risk are mitigated by the analysis in Section 4.2.4. Thus, the focus in this section is on potential differences between workers affected and workers unaffected by the reform and labor market characteristics that may interact with our findings.

Occupations In our main tests, we measure unemployment risk at the firm level. Since unemployment risk may vary within the same firm, we replicate our main tests computing layoff risk separately for high-skilled and low-skilled workers in the same firm and saturate equation (5) with firm-skill-time, age group-skill-time, and firm-worker group-skill fixed effects. Thus, we compare affected and unaffected workers within the same firm, skill level, and month, also controlling for time trends among people in the same age group and occupation.

The results are shown in Table A.3. Employment declines by 0.41 percent (column I) and hiring rates decline by 0.02 percent (column III) per risk decile for workers affected by the reform. Wages and hiring wages for workers affected by the reform increase by 0.20 and 0.09 percent more per risk decile after the reform (columns II and IV). This suggests that our results are robust to measuring layoff risk at different levels of granularity and are not driven by differences in workers' skill level. 
Tenure-Wage Growth Profile Workers affected and workers unaffected by the reform have different average tenures. As a consequence, they may be on a different wage growth trajectory. To predict a worker's wage based on their tenure-wage profile, we compute the average wage growth of workers with the same tenure and define the difference in the observed and the predicted wage as excess wage growth $\left(\log (\text { wage })_{j t}^{e}=\log (\text { wage })_{j t}-\right.$ $\log (\text { wage })_{j t}^{\text {predicted }}$ ) and replace the dependent variable in equations (4) and (5).

We find that adjusting for wage growth based on workers' tenure-wage trajectory does not affect the results (Table A.4). Excess wage growth is 0.69 percent higher for workers affected by the reform compared to workers unaffected by the reform (column I). As before, we find that this effect is stronger for riskier firms, increasing by 16 to 28 basis points per increase in risk decile (columns II to IV). We find the same patterns for newly hired workers. ${ }^{22}$

To account for the possibility that the wage-tenure profile is not linear, we control for workers' tenure and all its interactions with the independent variables in equation (5). The results reported in Table A.5 are very similar to the benchmark specification from Tables 3 and 4.

Altogether, these results suggest that differential changes in wages for workers affected and unaffected by the reform are not explained by differences in their tenure-wage profile.

Labor Market Informality Informality is a pervasive feature of labor markets in Brazil. To examine to what extent the presence of informal labor markets affects our results, we split the sample into above- and below-median levels of labor market informality across municipalities and industries in Brazil. ${ }^{23}$

The results for above- and below-median levels of labor market informality are shown in Tables A.6 (municipality level) and A.7 (industry level). We find that the effects are present in both high- and low-informality labor markets.

\section{Conclusion}

In this paper, we examine how unemployment insurance affects the allocation of labor supply across firms that expose workers to different levels of unemployment risk. Exploiting a reform in Brazil that alters eligibility criteria for part of the workforce allows us to control for firms' labor demand by examining changes in employment and wages for different workers within the same firm. We find that a reduction in the generosity of UI reduces labor supply to riskier firms, forcing them to pay higher compensating wage differentials.

\footnotetext{
${ }^{22}$ For newly hired workers, we use the tenure at their previous job.

${ }^{23}$ Information on labor market informality is from the Brazilian Census.
} 
Lower labor supply and higher labor costs are consistent with a relative decline in risky firms' value following the announcement of the reform.

These findings imply that a more generous UI system subsidizes risky firms' labor costs and establishes a transfer system from safe to risky firms. We find that, as a consequence, in areas in which a larger fraction of the workforce is affected by a reduction in UI generosity, entrepreneurship declines after the reform. This suggests that encouraging corporate risk-taking is an important policy externality of UI. An additional implication of our findings is that reducing compensating differentials through the provision of UI may affect the composition of firms' production factors.

The theory of second-best (Lipsey and Lancaster 1956) cautions us against general welfare statements. Whether encouraging risk-taking in the economy has benign or malign effects on growth depends on whether workers are risk averse to the extent that profitable risky activities become unprofitable after taking into account compensating wage differentials. Typically, workers are thought to be risk averse and have been shown to demand compensating wage differentials for exposure to unemployment risk. This may constitute an implicit tax on corporate risk-taking and drive it to below optimal levels. In this case, UI reduces the implicit tax on corporate risk-taking and brings it closer to its optimal level.

\section{References}

Abowd, J. M., and O. C. Ashenfelter. 1981. Anticipated unemployment, temporary layoffs, and compensating wage differentials. In Studies in Labor Markets, pp. 141170, University of Chicago Press.

Acemoglu, D., and R. Shimer. 1999. Efficient Unemployment Insurance. Journal of Political Economy 107:893-928.

Acemoglu, D., and F. Zilibotti. 1997. Was Prometheus Unbound by Chance? Risk, Diversification, and Growth. Journal of Political Economy 105:709-751.

Agrawal, A. K., and D. A. Matsa. 2013. Labor unemployment risk and corporate financing decisions. Journal of Financial Economics 108:449-470.

Amihud, Y., and B. Lev. 1981. Risk Reduction as a Managerial Motive for Conglomerate Mergers. Bell Journal of Economics 12:605-617.

Baghai, R., R. Silva, V. Thell, and V. Vig. 2019. Talent in Distressed Firms: Investigating the Labor Costs of Financial Distress. Working Paper. 
Barr, A., and S. Turner. 2015. Out of work and into school: Labor market policies and college enrollment during the Great Recession. Journal of Public Economics 124:63 73.

Berk, J. B., R. Stanton, and J. Zechner. 2010. Human Capital, Bankruptcy, and Capital Structure. Journal of Finance 65:891-926.

Brown, J., and D. A. Matsa. 2016. Boarding a Sinking Ship? An Investigation of Job Applications to Distressed Firms. Journal of Finance 71:507-550.

Fagereng, A., L. Guiso, and L. Pistaferri. 2017. Portfolio Choices, Firm Shocks, and Uninsurable Wage Risk. Review of Economic Studies 85:437-474.

Fazio, D., T. Silva, and J. Skrastins. 2019. Court Congestion, Transmission of Shocks, and Vertical Integration. Working Paper.

Gormley, T. A., and D. A. Matsa. 2016. Playing it safe? Managerial Preferences, Risk, and Agency Conflicts. Journal of Financial Economics 122:431-455.

Hamermesh, D. S. 1979. Entitlement Effects, Unemployment Insurance, and Employment Decisions. Economic Enquiry 17:317-332.

Hamermesh, D. S., and J. R. Wolfe. 1990. Compensating Wage Differentials and the Duration of Wage Loss. Journal of Labor Economics 8:S175-S197.

Holmström, B. 1999. Managerial Incentive Problems: A Dynamic Perspective. Review of Economic Studies 66:169-182.

Hombert, J., A. Schoar, D. Sraer, and D. Thesmar. 2020. Can Unemployment Insurance Spur Entrepreneurial Activity? Evidence from France. Journal of Finance.

Hsu, J. W., D. A. Matsa, and B. T. Melzer. 2018. Unemployment Insurance as a Housing Market Stabilizer. American Economic Review 108:49-81.

Jaeger, S., B. Schoefer, S. Young, and J. Zweimueller. forthcoming. Wages and the Value of Nonemployment. Quarterly Journal of Economics .

Jensen, M. C., and W. H. W. Meckling. 1976. Theory of the firm: Managerial behavior, agency costs and ownership structure. Journal of Financial Economics 3:305-360.

Kuka, E. forthcoming. Quantifying the Benefits of Social Insurance: Unemployment Insurance and Health. Review of Economics and Statistics .

Lamadon, T. 2014. Productivity Shocks, Long-Term Contracts and Earnings Dynamics. Working Paper. 
Levine, R., and S. Zervos. 1998. Stock Markets, Banks, and Economic Growth. American Economic Review 88:537-558.

Li, E. H. 1986. Compensating Differentials for Cyclical and Noncyclical Unemployment: The Interaction between Investors' and Employees' Risk Aversion. Journal of Labor Economics 4:277-300.

Lipsey, R. G., and K. Lancaster. 1956. The General Theory of Second Best. Review of Economic Studies 24:11-32.

MacKinlay, A. C. 1997. Event Studies in Economics and Finance. Journal of Economic Literature 35:13-39.

Mueller, H. M., P. P. Ouimet, and E. Simintzi. 2017. Wage inequality and firm growth. American Economic Review, Papers and Proceedings 105:379-383.

Murphy, K. J. 1999. Chapter 38 Executive compensation. In O. C. Ashenfelter and D. Card (eds.), Handbook of Labor Economics, vol. 3, pp. 2485-2563, Elsevier.

Peters, F. S., and A. F. Wagner. 2014. The Executive Turnover Risk Premium. Journal of Finance 69:1529-1563.

Rosen, S. 1986. Chapter 12 The theory of equalizing differences. In O. C. Ashenfelter (ed.), Handbook of Labor Economics, vol. 1, pp. 641-692, Elsevier.

Schoenherr, D., and J. Starmans. 2019. When Should Bankruptcy Law Be Creditor- or Debtor-Friendly? Theory and Evidence. Working Paper.

Smith, C. W., and R. M. Stulz. 1985. The Determinants of Firms' Hedging Policies. Journal of Financial and Quantitative Analysis 20:391-405.

Topel, R. H. 1984. Equilibrium Earnings, Turnover, and Unemployment: New Evidence. Journal of Labor Economics 2:500-522.

Tufano, P. 1996. Who Manages Risk? An Empirical Examination of Risk Management Practices in the Gold Mining Industry. Journal of Finance 51:1097-1137. 
Figure 1: UI Eligibility Around the Reform

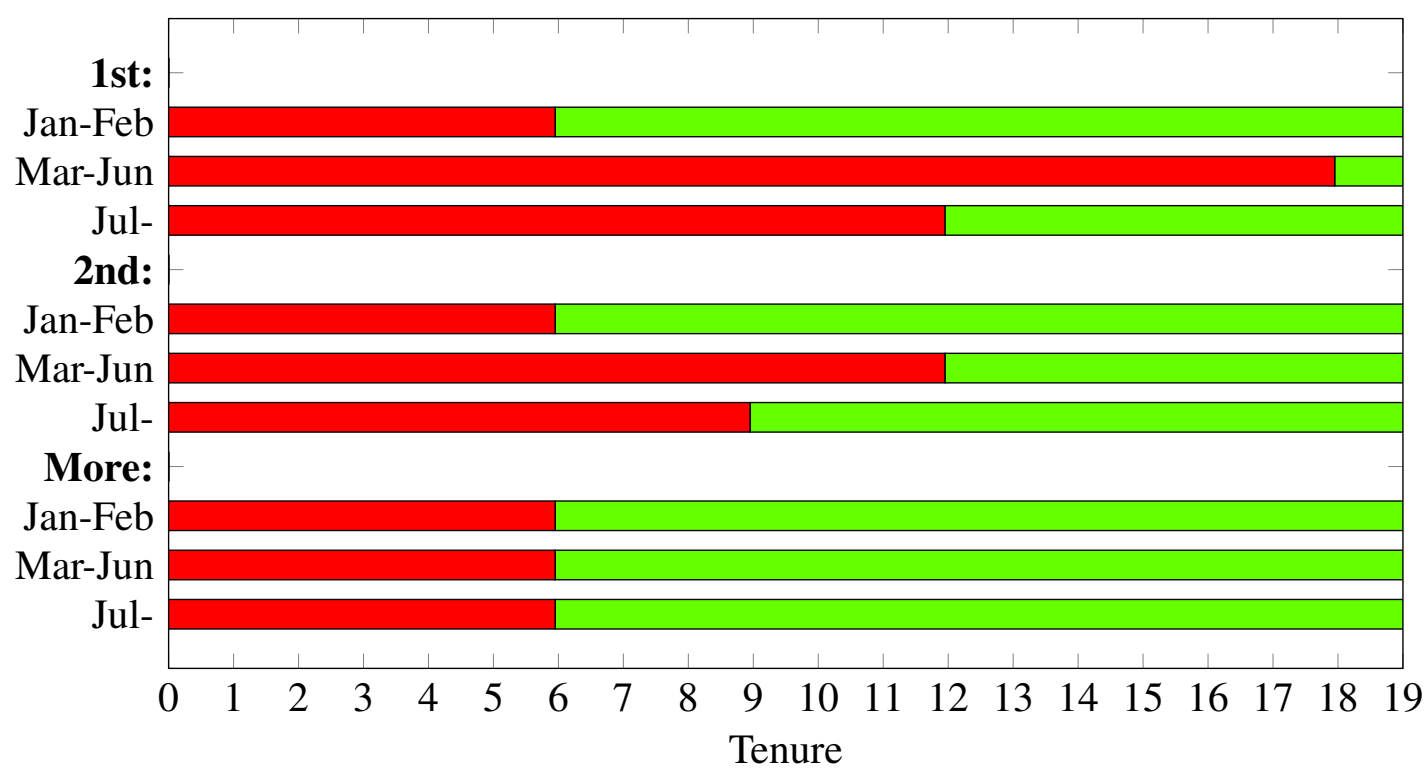

ineligible $\square$ eligible

This figure illustrates eligibility criteria for UI benefits before and after the reform conditional on workers' tenure. The top lines depict eligibility criteria for workers with no prior UI benefits spell, the middle lines for workers with one prior benefits spell, and the bottom lines for workers with at least two prior benefits spells. Tenure ranges that do not satisfy eligibility criteria are indicated in red; tenure ranges that satisfy eligibility criteria are indicated in green. 


\section{Figure 2: Employment and Wages}

Employment

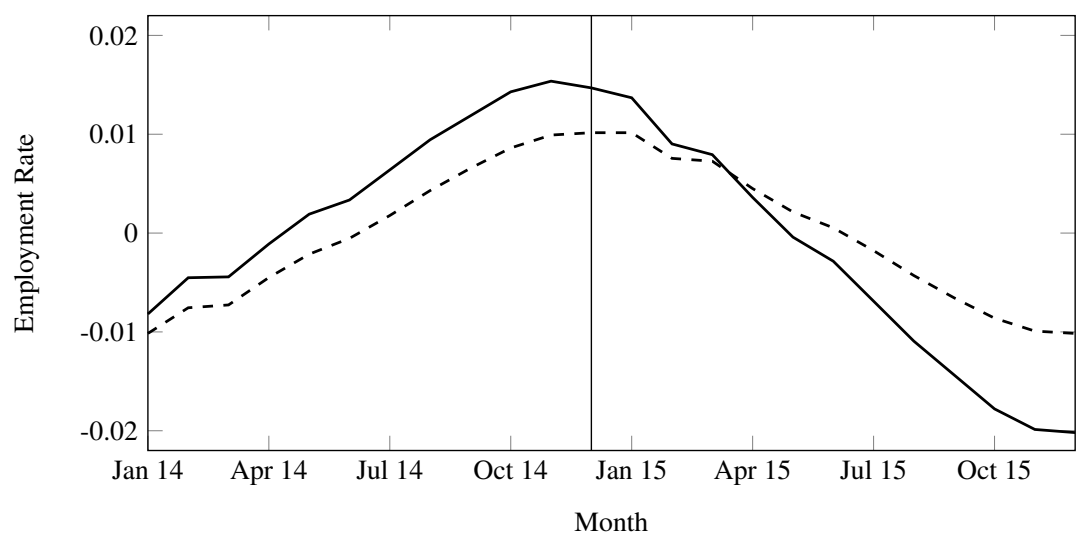

Hiring

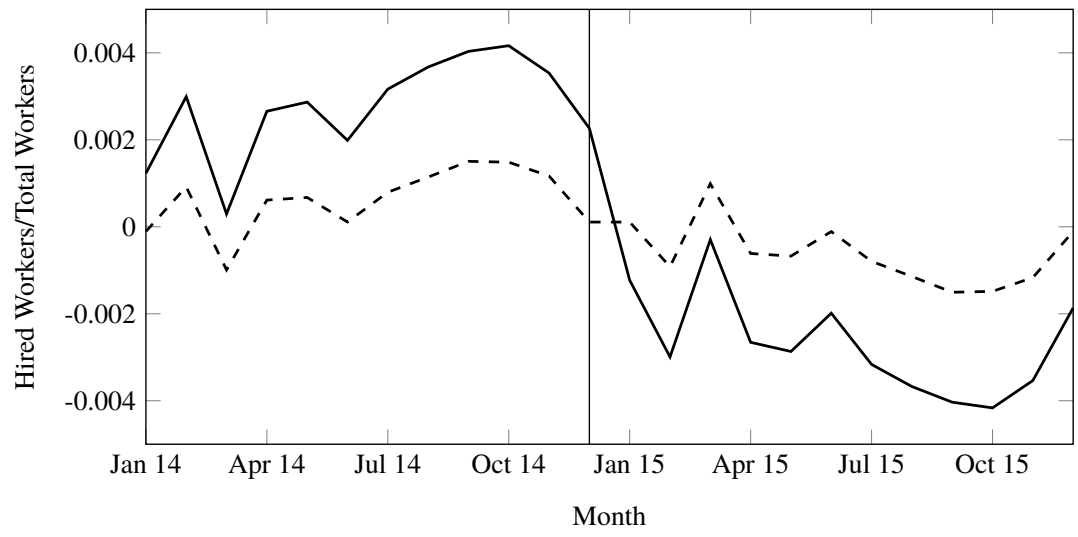

Wages

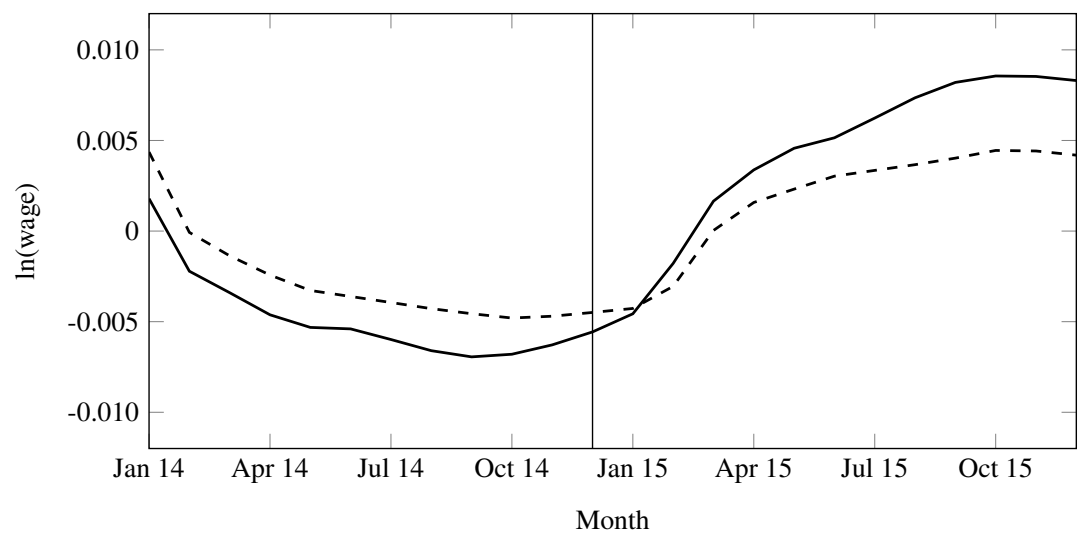

Hiring Wage

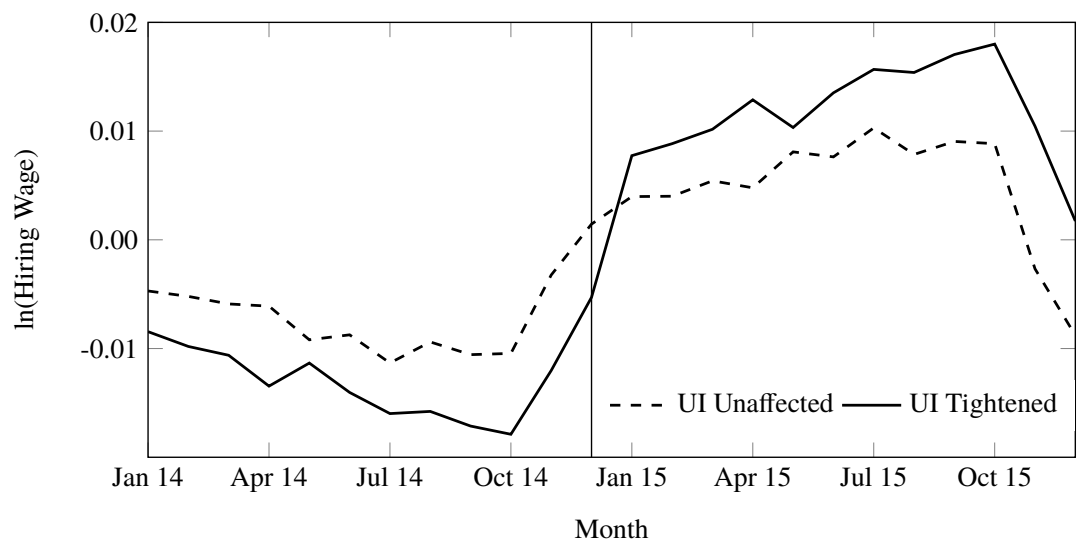

This figure depicts time-series changes in total employment, wages, hiring, and hiring wages around the announcement of the UI reform. The top left panel depicts total employment of workers with one or fewer prior UI benefits spells (solid line) and workers with at least two prior UI benefits spells (dashed line) scaled by total employment at the end of 2014. The top right panel depicts the average log wage, the left bottom panel depicts hiring rates, and the bottom right panel depicts hiring wages. All plots are adjusted for firm, worker group, and calendar month fixed effects. 


\section{Figure 3: Employment, Wages, and Firm Risk}
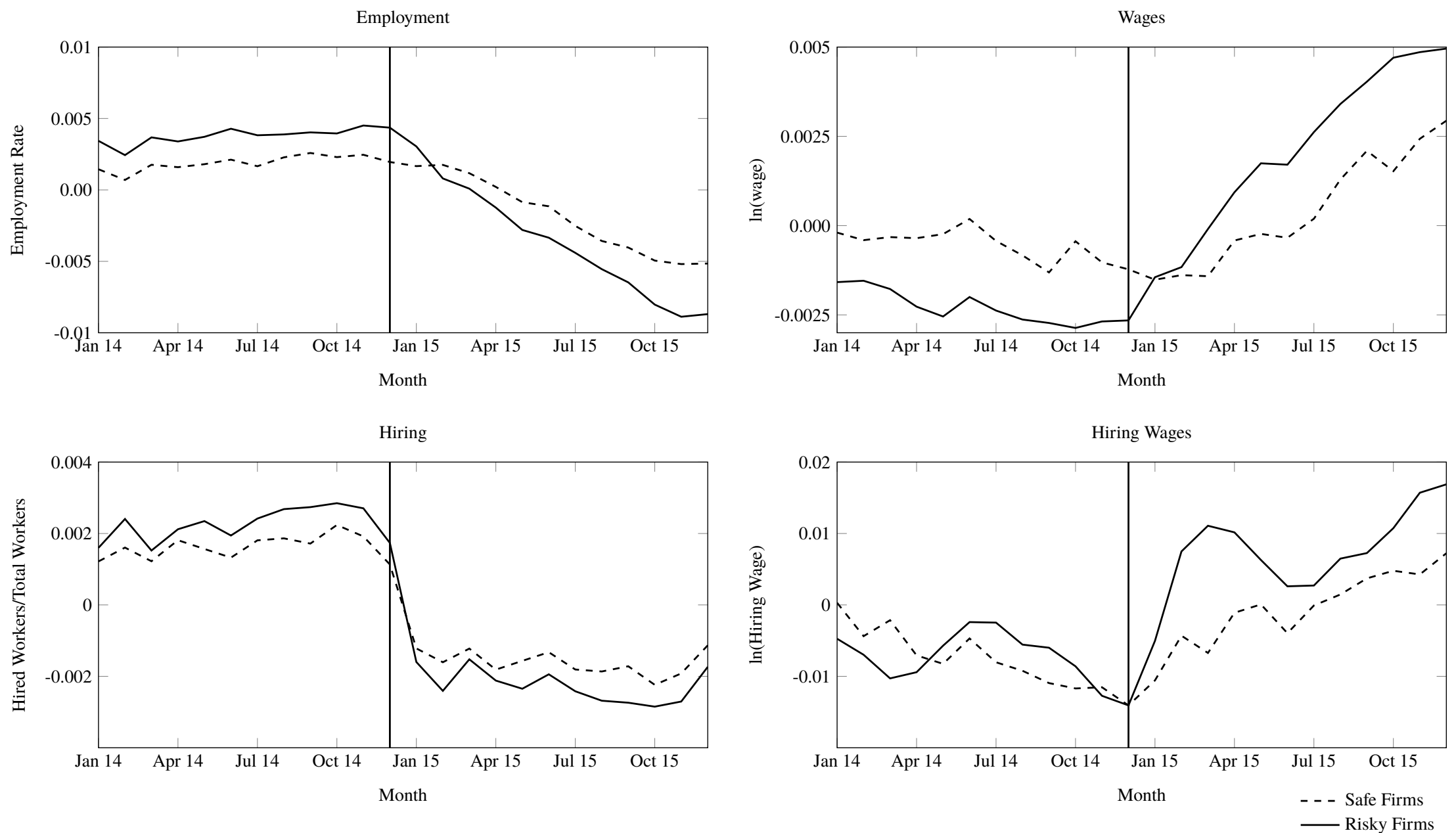

This figure depicts time-series changes in total employment, wages, hiring, and hiring wages around the announcement of the UI reform. The plots in the top left panel depict the difference in employment of workers with one or no prior UI benefits spells and workers with at least two prior UI benefits spells for risky (solid line) and safe (dashed line) firms, where risky firms are defined as firms in the top quartile of credit risk. The top right panel depicts the same difference for the log average wage, the bottom left panel for hiring rates, the bottom right panel for log hiring wages. All plots are adjusted for firm, worker group, and calendar month fixed effects. 
Figure 4: Cumulative Abnormal Returns by Firm Risk
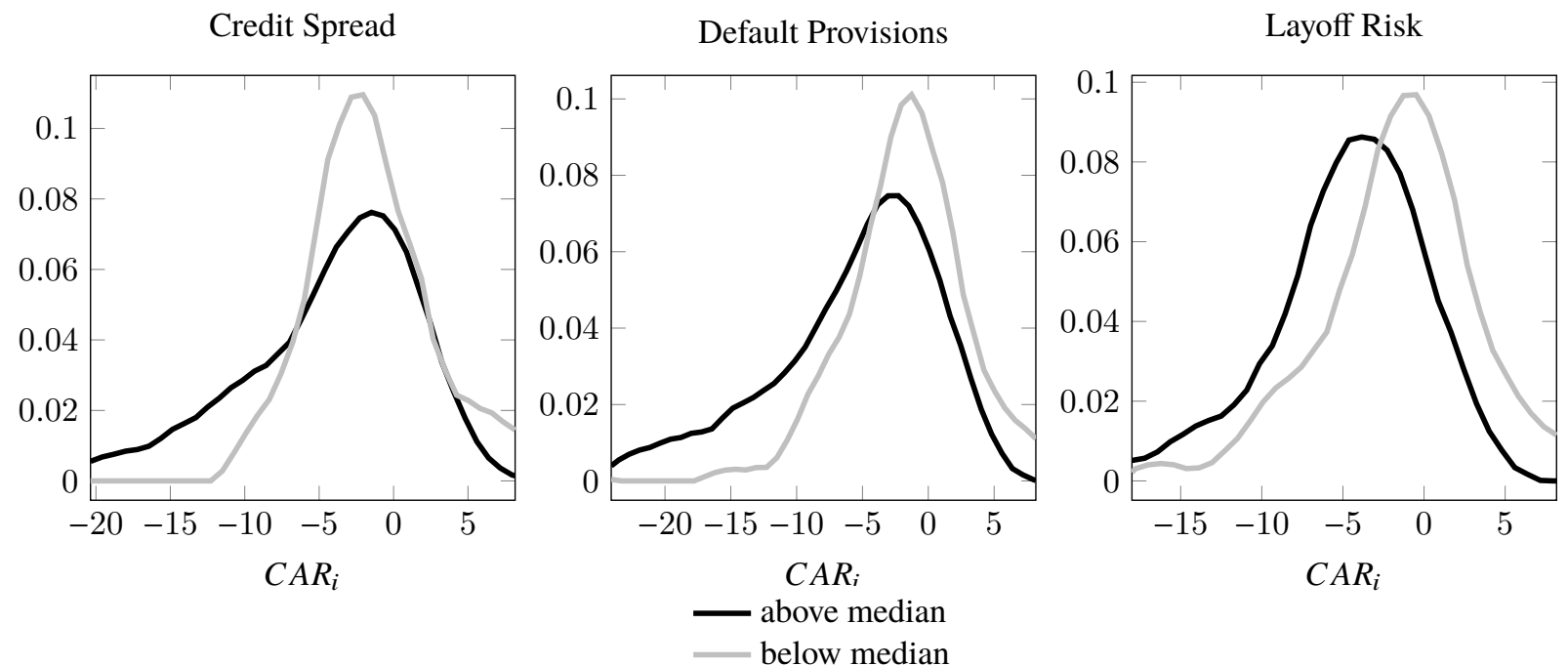

This figure depicts the distribution of cumulated abnormal returns of firms with above- and below-median levels of firm risk over the 5 days around the announcement of the UI reform on December 29, 2014. Firm risk is measured by firms' credit spread in the left panel, default provisions that banks hold for firms' debt in the middle panel, and layoff risk in the right panel. 


\section{Figure 5: Entrepreneurship}

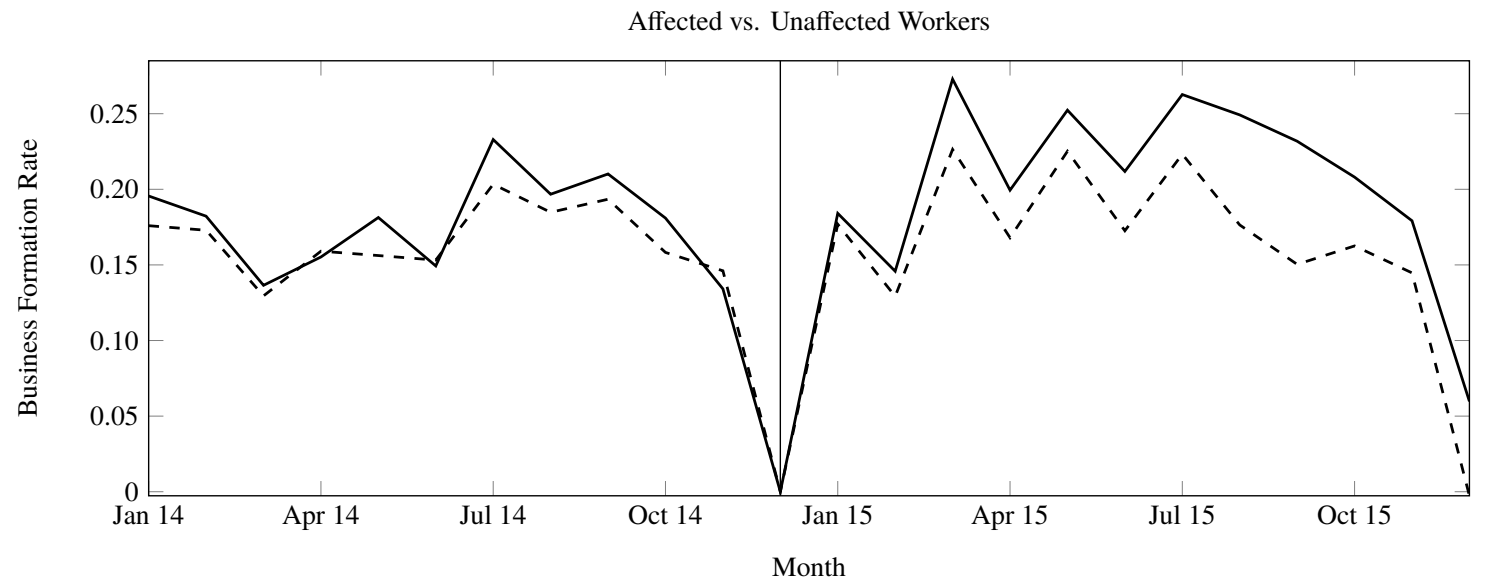

Affected vs. Unaffected Municipalities

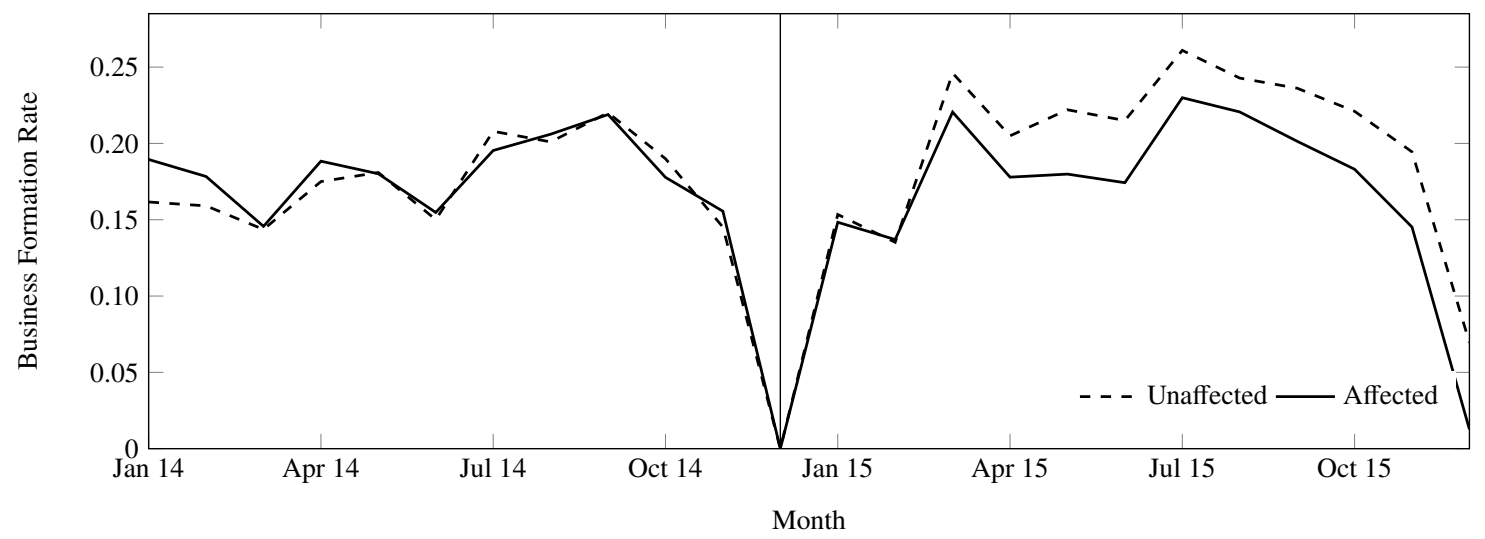

This figure depicts time-series changes in business formation rates (log of number of businesses) around the announcement of the UI reform. In the top panel, the plots depict business formation rates for workers with one or no prior UI benefits spell (solid line) and workers with at least two prior UI benefits spells (dashed line). In the bottom panel, the plots depict business formation rates for municipalities with above-median levels of the fraction of workers affected by the reform (solid line) and municipalities with below-median levels of the fraction of workers affected by the reform (dashed line). All plots are normalized to be zero in December 2014. 
Figure 6: Fraction of Affected Population by Municipality

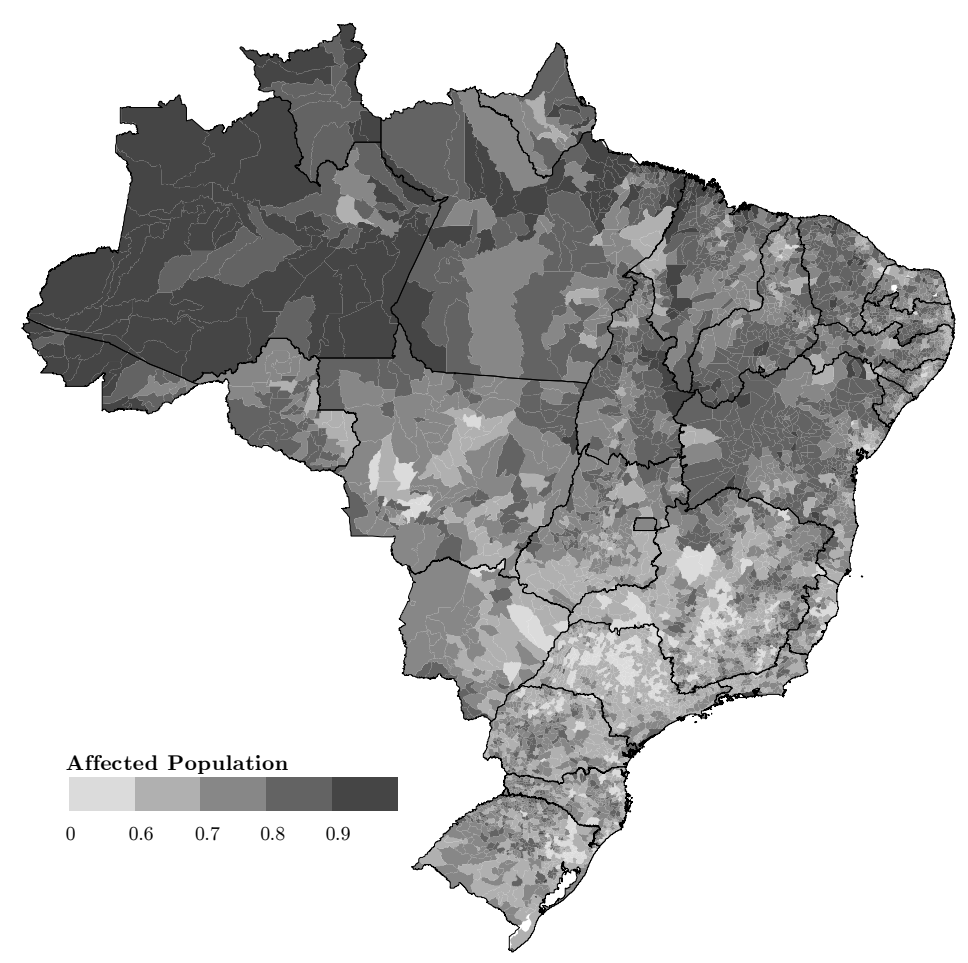

This figure depicts the share of the working-age population in a municipality affected by the UI reforn. 
Table 1: Summary Statistics

\begin{tabular}{|c|c|c|c|c|}
\hline \multicolumn{5}{|c|}{ Panel A: Employment measures by group } \\
\hline & All & Affected & Unaffected & Difference \\
\hline Number of Workers ('000) & 24,772 & 17,182 & 7,590 & \\
\hline Average Wage & 1,964 & 1,978 & 1,951 & 27 \\
\hline Number of New Hires ('000) & 716 & 468 & 248 & \\
\hline Average Wage for New Hires & 1,721 & 1,722 & 1,719 & 3 \\
\hline Education & 0.652 & 0.655 & 0.649 & 0.006 \\
\hline Age & 36.5 & 35.0 & 39.8 & $-4.8 * * *$ \\
\hline Tenure (months) & 33.9 & 36.0 & 32.4 & $3.6 * * *$ \\
\hline Skilled Occupation & 0.222 & 0.237 & 0.207 & $0.030 * * *$ \\
\hline Entrepreneur & 0.082 & 0.080 & 0.089 & -0.009 \\
\hline Manufacturing & 0.107 & 0.117 & 0.135 & -0.018 \\
\hline Agriculture & 0.050 & 0.046 & 0.068 & -0.022 \\
\hline Construction & 0.011 & 0.010 & 0.014 & -0.004 \\
\hline \multicolumn{5}{|l|}{ Panel B: Firm-level measures } \\
\hline & Mean & Median & Std. Dev. & \\
\hline 12 months Layoff Rate & $\overline{0.180}$ & 0.150 & 0.152 & \\
\hline Interest Spread & 1.203 & 0.410 & 1.314 & \\
\hline Default Provisions & 0.080 & 0.010 & 0.219 & \\
\hline
\end{tabular}

This table reports descriptive statistics in December 2014. Panel A reports worker-level information: the number of workers and their wages, the number of new hires and their wages, education, which equals one if a worker has completed secondary education and zero otherwise, age, tenure, skills, which equals one if a worker is employed in a high-skill occupation and zero otherwise, entrepreneur, which equals one if an individual owns a firm and zero otherwise, and the fraction of workers employed in manufacturing, agriculture, and construction. Values are reported separately for all workers, for workers with fewer than two prior UI benefits spells (affected), and for workers with at least two prior UI benefits spells (unaffected). The last column reports the difference between affected and unaffected workers, where $* * *$ denotes statistical significance at the $1 \%$ level. Panel B reports firm-level statistics: the probability of a newly hired worker being laid off within 12 months, the highest credit spread among all active bank liabilities, and loan default provisions held at the central bank (fraction of outstanding debt). 
Table 2: Employment, Hiring, and Wages

\begin{tabular}{|c|c|c|c|c|}
\hline \multirow[b]{2}{*}{ Dep. Var.: } & \multicolumn{2}{|c|}{ Employed Workers } & \multicolumn{2}{|c|}{ Hired Workers } \\
\hline & $\begin{array}{c}\text { ERate } \\
\text { I }\end{array}$ & $\begin{array}{c}\log (\text { wage }) \\
\text { II }\end{array}$ & $\begin{array}{c}\text { HiringRate } \\
\text { III }\end{array}$ & $\begin{array}{c}\log (\text { wage }) \\
\text { IV }\end{array}$ \\
\hline \multicolumn{5}{|l|}{ Panel A: Main Tests } \\
\hline Affected $_{j} *$ Reform $_{t}$ & $\begin{array}{c}-0.0594 * * * \\
(0.0007)\end{array}$ & $\begin{array}{c}0.0090 * * * \\
(0.0006)\end{array}$ & $\begin{array}{c}-0.0052 * * * \\
(0.0001)\end{array}$ & $\begin{array}{c}0.0252 * * * \\
(0.0009)\end{array}$ \\
\hline $\begin{array}{l}\text { Firm*Affected FE } \\
\text { Firm*Month FE } \\
\text { Age Group*Month FE } \\
\text { Clustered SE }\end{array}$ & $\begin{array}{l}\text { yes } \\
\text { yes } \\
\text { yes } \\
\text { firm }\end{array}$ & $\begin{array}{l}\text { yes } \\
\text { yes } \\
\text { yes } \\
\text { firm }\end{array}$ & $\begin{array}{l}\text { yes } \\
\text { yes } \\
\text { yes } \\
\text { firm }\end{array}$ & $\begin{array}{l}\text { yes } \\
\text { yes } \\
\text { yes } \\
\text { firm }\end{array}$ \\
\hline $\begin{array}{l}\text { Observations } \\
R^{2}\end{array}$ & $\begin{array}{c}21,280,320 \\
0.520\end{array}$ & $\begin{array}{c}17,144,583 \\
0.772\end{array}$ & $\begin{array}{c}21,280,320 \\
0.415\end{array}$ & $\begin{array}{c}4,696,198 \\
0.720\end{array}$ \\
\hline \multicolumn{5}{|c|}{ Panel B: Workers Around Threshold } \\
\hline Affected $_{j} *$ Reform $_{t}$ & $\begin{array}{c}-0.0218 * * * \\
(0.0006)\end{array}$ & $\begin{array}{c}0.0052 * * * \\
(0.0007)\end{array}$ & $\begin{array}{c}-0.0034 * * * \\
(0.0001)\end{array}$ & $\begin{array}{c}0.0134 * * * \\
(0.0010)\end{array}$ \\
\hline $\begin{array}{l}\text { Firm*Affected FE } \\
\text { Firm*Month FE } \\
\text { Age Group*Month FE } \\
\text { Clustered SE }\end{array}$ & $\begin{array}{l}\text { yes } \\
\text { yes } \\
\text { yes } \\
\text { firm }\end{array}$ & $\begin{array}{l}\text { yes } \\
\text { yes } \\
\text { yes } \\
\text { firm }\end{array}$ & $\begin{array}{l}\text { yes } \\
\text { yes } \\
\text { yes } \\
\text { firm }\end{array}$ & $\begin{array}{l}\text { yes } \\
\text { yes } \\
\text { yes } \\
\text { firm }\end{array}$ \\
\hline $\begin{array}{l}\text { Observations } \\
R^{2}\end{array}$ & $\begin{array}{c}21,075,120 \\
0.607\end{array}$ & $\begin{array}{c}15,098,045 \\
0.746\end{array}$ & $\begin{array}{c}21,276,432 \\
0.291\end{array}$ & $\begin{array}{c}3,066,844 \\
0.733\end{array}$ \\
\hline
\end{tabular}

This table reports changes in employment and wages around the UI reform. The dependent variable is the employment of workers affected or unaffected by the reform by firm $i$ in month $t$ over total employment in December 2014 in column I, the log average wage in column II, the number of workers hired relative to a firm's employment in December 2014 in column III, and the average log hiring wage in column IV. In Panel $\mathrm{B}$, the sample is limited to workers with one or two prior UI benefits spells. The variable Affected $d_{j}$ takes the value of one for workers with fewer than two prior UI benefits spells and zero for workers with two or more prior UI benefits spells. The variable Re form $t$ takes the value of one for the post-reform period from January 2015 to December 2016 and zero for the pre-reform period from January 2013 to December 2014. Standard errors are reported in parentheses. The bottom part of the table reports information on fixed effects and the clustering of standard errors. *** denotes statistical significance at the $1 \%$ level. 
Table 3: Firm Risk and Labor Supply - Employment

\begin{tabular}{|c|c|c|c|c|c|c|}
\hline \multirow{3}{*}{$\begin{array}{l}\text { Risk Measure: } \\
\text { Dep. Var.: }\end{array}$} & \multicolumn{2}{|c|}{ Credit Spread } & \multicolumn{2}{|c|}{ Default Provisions } & \multicolumn{2}{|c|}{ Layoff Risk } \\
\hline & ERate & $\log ($ wage $)$ & ERate & $\log ($ wage $)$ & ERate & $\log ($ wage $)$ \\
\hline & I & II & III & IV & $\mathrm{V}$ & VI \\
\hline \multicolumn{7}{|l|}{ Panel A: Main Tests } \\
\hline Affected $_{j} *$ Reform $_{t}$ & $\begin{array}{c}-0.0476 * * * \\
(0.0017)\end{array}$ & $\begin{array}{c}0.0054 * * * \\
(0.0016)\end{array}$ & $\begin{array}{c}-0.0435 * * * \\
(0.0016)\end{array}$ & $\begin{array}{c}0.0046 * * * \\
(0.0015)\end{array}$ & $\begin{array}{c}-0.0203 * * * \\
(0.0020)\end{array}$ & $\begin{array}{c}-0.0083 * * * \\
(0.0015)\end{array}$ \\
\hline Affected $_{j} * \operatorname{Reform}_{t} *$ Risk $_{i}$ & $\begin{array}{c}-0.0027 * * * \\
(0.0003)\end{array}$ & $\begin{array}{c}0.0006 * * \\
(0.0003)\end{array}$ & $\begin{array}{c}-0.0039 * * * \\
(0.0003)\end{array}$ & $\begin{array}{c}0.0008 * * * \\
(0.0003)\end{array}$ & $\begin{array}{c}-0.0067 * * * \\
(0.0003)\end{array}$ & $\begin{array}{c}0.0029 * * * \\
(0.0002)\end{array}$ \\
\hline Firm*Affected FE & yes & yes & yes & yes & yes & yes \\
\hline Firm*Month FE & yes & yes & yes & yes & yes & yes \\
\hline Age Group*Month FE & yes & yes & yes & yes & yes & yes \\
\hline Clustered SE & firm & firm & firm & firm & firm & firm \\
\hline Observations & $16,766,784$ & $13,835,418$ & $16,766,784$ & $13,835,418$ & $21,280,320$ & $17,144,583$ \\
\hline$R^{2}$ & 0.544 & 0.760 & 0.544 & 0.760 & 0.520 & 0.768 \\
\hline \multicolumn{7}{|c|}{ Panel B: Workers Around Threshold } \\
\hline Affected $_{j} *$ Re form $_{t}$ & $\begin{array}{c}-0.0103 * * * \\
(0.0014)\end{array}$ & $\begin{array}{c}-0.0004 \\
(0.0018)\end{array}$ & $\begin{array}{c}-0.0078 * * * \\
(0.0013)\end{array}$ & $\begin{array}{l}-0.0020 \\
(0.0017)\end{array}$ & $\begin{array}{c}0.0061 * * * \\
(0.0015)\end{array}$ & $\begin{array}{c}-0.0053^{* * *} \\
(0.0017)\end{array}$ \\
\hline Affected $_{j} * \operatorname{Reform}_{t} * \operatorname{Ris}_{i}$ & $\begin{array}{c}-0.0024 * * * \\
(0.0002)\end{array}$ & $\begin{array}{c}0.0008 * * * \\
(0.0003)\end{array}$ & $\begin{array}{c}-0.0033 * * * \\
(0.0003)\end{array}$ & $\begin{array}{c}0.0012 * * * \\
(0.0003)\end{array}$ & $\begin{array}{c}-0.0048 * * * \\
(0.0002)\end{array}$ & $\begin{array}{c}0.0018 * * * \\
(0.0003)\end{array}$ \\
\hline Firm*Affected FE & yes & yes & yes & yes & yes & yes \\
\hline Firm*Month FE & yes & yes & yes & yes & yes & yes \\
\hline Age Group*Month FE & yes & yes & yes & yes & yes & yes \\
\hline Clustered SE & firm & firm & firm & firm & firm & firm \\
\hline Observations & $16,707,168$ & $12,251,579$ & $16,707,168$ & $12,251,579$ & $21,075,120$ & $15,098,045$ \\
\hline$R^{2}$ & 0.629 & 0.737 & 0.629 & 0.737 & 0.607 & 0.746 \\
\hline
\end{tabular}

This table reports changes in employment and wages around the UI reform. The dependent variable is the employment of workers affected or unaffected by the reform by firm $i$ in month $t$ over total employment in December 2014 in odd columns, and the log average wage in even columns. In Panel B, the sample is limited to workers with one or two prior UI benefits spells. The variable Affected ${ }_{j}$ takes the value of one for workers with fewer than two prior UI benefits spells and zero for workers with two or more prior UI benefits spells. The variable Reform $t$ takes the value of one for the post-reform period from January 2015 to December 2016 and zero for the pre-reform period from January 2013 to December 2014. The variable $R i s k_{i}$ takes the values of one for the safest to ten for the riskiest decile of firms. Standard errors are reported in parentheses. The bottom part of the table reports information on fixed effects and the clustering of standard errors. *** and $* *$ denote statistical significance at the $1 \%$ and $5 \%$ levels, respectively. 
Table 4: Firm Risk and Labor Supply - Hiring

\begin{tabular}{|c|c|c|c|c|c|c|}
\hline \multirow{3}{*}{$\begin{array}{l}\text { Risk Measure: } \\
\text { Dep. Var.: }\end{array}$} & \multicolumn{2}{|c|}{ Credit Spread } & \multicolumn{2}{|c|}{ Default Provisions } & \multicolumn{2}{|c|}{ Layoff Risk } \\
\hline & Hiring Rate & $\log ($ wage $)$ & HiringRate & $\log ($ wage $)$ & HiringRate & $\log ($ wage $)$ \\
\hline & $\mathrm{I}$ & II & III & IV & $\mathrm{V}$ & $\mathrm{VI}$ \\
\hline \multicolumn{7}{|l|}{ Panel A: Main Tests } \\
\hline Affected f $_{j} *$ Reform $_{t}$ & $\begin{array}{c}-0.0007 * * * \\
(0.0001)\end{array}$ & $\begin{array}{c}0.0191 * * * \\
(0.0022)\end{array}$ & $\begin{array}{c}-0.0049 * * * \\
(0.0001)\end{array}$ & $\begin{array}{c}0.0210 * * * \\
(0.0020)\end{array}$ & $\begin{array}{c}-0.0048 * * * \\
(0.0001)\end{array}$ & $\begin{array}{c}0.0157 * * * \\
(0.0022)\end{array}$ \\
\hline Affected $_{j} * \operatorname{Reform}_{t} *$ Risk $_{i}$ & $\begin{array}{c}-0.0002 * * * \\
(0.0000)\end{array}$ & $\begin{array}{c}0.0011 * * * \\
(0.0003)\end{array}$ & $\begin{array}{c}-0.0001 * * * \\
(0.0000)\end{array}$ & $\begin{array}{c}0.0009 * * \\
(0.0004)\end{array}$ & $\begin{array}{c}-0.0001 * * * \\
(0.0000)\end{array}$ & $\begin{array}{c}0.0016 * * * \\
(0.0003)\end{array}$ \\
\hline Firm*Affected FE & yes & yes & yes & yes & yes & yes \\
\hline Firm*Month FE & yes & yes & yes & yes & yes & yes \\
\hline Age Group*Month FE & yes & yes & yes & yes & yes & yes \\
\hline Clustered SE & firm & firm & firm & firm & firm & firm \\
\hline Observations & $16,766,784$ & $3,996,047$ & $16,766,784$ & $3,996,047$ & $21,280,320$ & $4,696,198$ \\
\hline$R^{2}$ & 0.422 & 0.710 & 0.422 & 0.710 & 0.415 & 0.720 \\
\hline \multicolumn{7}{|c|}{ Panel B: Workers Around Threshold } \\
\hline Affected f $_{j} *$ Reform $_{t}$ & $\begin{array}{c}-0.0025 * * * \\
(0.0001)\end{array}$ & $\begin{array}{c}0.0034 \\
(0.0026)\end{array}$ & $\begin{array}{c}-0.0027 * * * \\
(0.0001)\end{array}$ & $\begin{array}{c}0.0093 * * * \\
(0.0024)\end{array}$ & $\begin{array}{c}-0.0021 * * * \\
(0.0001)\end{array}$ & $\begin{array}{l}0.0047 * \\
(0.0026)\end{array}$ \\
\hline Affected $_{j} *$ Reform $_{t} *$ Risk $_{i}$ & $\begin{array}{c}-0.0002 * * * \\
(0.0001)\end{array}$ & $\begin{array}{c}0.0018 * * * \\
(0.0004)\end{array}$ & $\begin{array}{c}-0.0002 * * * \\
(0.0000)\end{array}$ & $\begin{array}{l}0.0008^{*} \\
(0.0004)\end{array}$ & $\begin{array}{c}-0.0002 * * * \\
(0.0001)\end{array}$ & $\begin{array}{c}0.0015 * * * \\
(0.0004)\end{array}$ \\
\hline Firm*Affected FE & yes & yes & yes & yes & yes & yes \\
\hline Firm*Month FE & yes & yes & yes & yes & yes & yes \\
\hline Age Group*Month FE & yes & yes & yes & yes & yes & yes \\
\hline Clustered SE & firm & firm & firm & firm & firm & firm \\
\hline Observations & $16,707,168$ & $2,625,494$ & $16,707,168$ & $2,625,494$ & $21,075,120$ & $3,066,844$ \\
\hline$R^{2}$ & 0.373 & 0.722 & 0.373 & 0.722 & 0.363 & 0.733 \\
\hline
\end{tabular}

This table reports changes in hiring and wages around the announcement of the UI reform. The dependent variable is the share of workers hired relative to the firm's December 2014 employment (odd columns) or the log of hiring wage (even columns). In Panel B, the sample is limited to workers with one or two prior UI benefits spells. The variable Affected $f_{j}$ takes the value of one for workers with fewer than two prior UI benefits spells and zero for workers with two or more prior UI beneifts spells. The variable Re form takes the value of one for the post-reform period from January 2015 to December 2016 and zero for the pre-reform period from January 2013 to December 2014. The variable Risk $k_{i}$ takes the values of one for the safest to ten for the riskiest decile of firms. Standard errors are reported in parentheses. The bottom part of the table reports information on fixed effects and the clustering of standard errors. ***, **, and * denote statistical significance at the $1 \%, 5 \%$, and $10 \%$ levels, respectively. 
Table 5: Employment Transitions

\begin{tabular}{|c|c|c|c|c|c|c|}
\hline Dep. Var.: $\Delta R i s k_{i j t}$ & I & II & III & IV & $\mathrm{V}$ & VI \\
\hline Risk Measure: & \multicolumn{2}{|c|}{ Credit Spreads } & \multicolumn{2}{|c|}{ Default Provisions } & \multicolumn{2}{|c|}{ Layoff Risk } \\
\hline $\begin{array}{l}\text { Affected }_{j} * \text { Reform }_{t} \\
\text { Affected }_{j} * \text { Reform }_{t} * \operatorname{Risk}_{i}\end{array}$ & $\begin{array}{c}0.0032 * * * \\
(0.0004)\end{array}$ & $\begin{array}{c}-0.0020 * * * \\
(0.0005) \\
0.0009 * * * \\
(0.0001)\end{array}$ & $\begin{array}{c}0.0029 * * * \\
(0.0004)\end{array}$ & $\begin{array}{c}-0.0023 * * * \\
(0.0006) \\
0.0010 * * * \\
(0.0002) \\
\end{array}$ & $\begin{array}{c}0.0034 * * \\
(0.0005)\end{array}$ & $\begin{array}{c}-0.0009 \\
(0.0009) \\
0.0007 * * * \\
(0.0001)\end{array}$ \\
\hline $\begin{array}{l}\text { Firm*Affected FE } \\
\text { Firm*Month FE } \\
\text { Age Group*Month FE } \\
\text { Clustered SE }\end{array}$ & $\begin{array}{l}\text { yes } \\
\text { yes } \\
\text { yes } \\
\text { firm }\end{array}$ & $\begin{array}{l}\text { yes } \\
\text { yes } \\
\text { yes } \\
\text { firm }\end{array}$ & $\begin{array}{l}\text { yes } \\
\text { yes } \\
\text { yes } \\
\text { firm }\end{array}$ & $\begin{array}{l}\text { yes } \\
\text { yes } \\
\text { yes } \\
\text { firm }\end{array}$ & $\begin{array}{l}\text { yes } \\
\text { yes } \\
\text { yes } \\
\text { firm }\end{array}$ & $\begin{array}{l}\text { yes } \\
\text { yes } \\
\text { yes } \\
\text { firm }\end{array}$ \\
\hline $\begin{array}{l}\text { Observations } \\
R^{2}\end{array}$ & $\begin{array}{c}5,745,575 \\
0.178\end{array}$ & $\begin{array}{c}5,745,575 \\
0.178\end{array}$ & $\begin{array}{c}5,745,575 \\
0.232\end{array}$ & $\begin{array}{c}5,745,575 \\
0.232\end{array}$ & $\begin{array}{c}6,812,469 \\
0.188\end{array}$ & $\begin{array}{c}6,812,469 \\
0.189\end{array}$ \\
\hline
\end{tabular}

This table examines transitions of individuals to different firms around the UI reform. The dependent variable $\Delta R i s k_{i j t}$ is the fraction of workers who transition from a riskier to a safer firm. The variable

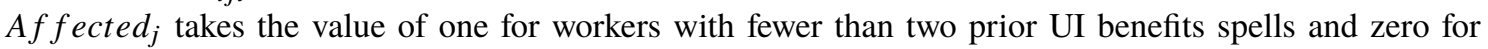
workers with two or more prior UI benefits spells. The variable Reform takes the value of one for the post-reform period from January 2015 to December 2016 and zero for the pre-reform period from January 2013 to December 2014. The variable Risk $k_{i}$ takes the values of one for the safest to ten for the riskiest decile of firms. Standard errors are reported in parentheses. The bottom part of the table reports information on fixed effects and the clustering of standard errors. $* * *$ and $* *$ denote statistical significance at the $1 \%$ and $5 \%$ levels, respectively. 


\section{Table 6: Number of UI Spells and Macro Economic Conditions}

\begin{tabular}{|c|c|c|c|c|c|c|c|c|c|c|c|c|}
\hline \multirow{3}{*}{$\begin{array}{l}\text { Risk Measure: } \\
\text { Dep. Var.: }\end{array}$} & \multicolumn{4}{|c|}{ Credit Spread } & \multicolumn{4}{|c|}{ Default Provisions } & \multicolumn{4}{|c|}{ Layoff Risk } \\
\hline & \multicolumn{2}{|c|}{ Employed } & \multicolumn{2}{|c|}{ Hiring } & \multicolumn{2}{|c|}{ Employed } & \multicolumn{2}{|c|}{ Hiring } & \multicolumn{2}{|c|}{ Employed } & \multicolumn{2}{|c|}{ Hiring } \\
\hline & $\begin{array}{c}\text { ERate } \\
\text { I }\end{array}$ & $\begin{array}{c}\log (\text { wage }) \\
\text { II }\end{array}$ & $\begin{array}{c}\text { Hiring Rate } \\
\text { III }\end{array}$ & $\begin{array}{c}\log (\text { wage }) \\
\text { IV }\end{array}$ & $\begin{array}{c}\text { ERate } \\
\mathrm{V}\end{array}$ & $\begin{array}{c}\log (\text { wage }) \\
\text { VI }\end{array}$ & $\begin{array}{c}\text { HiringRate } \\
\text { VII }\end{array}$ & $\begin{array}{c}\log (\text { wage }) \\
\text { VIII }\end{array}$ & $\begin{array}{c}\text { ERate } \\
\text { IX }\end{array}$ & $\begin{array}{c}\log (\text { wage }) \\
\mathrm{X}\end{array}$ & $\begin{array}{c}\text { Hiring Rate } \\
\text { XI }\end{array}$ & $\begin{array}{c}\log (\text { wage }) \\
\text { XII }\end{array}$ \\
\hline \multicolumn{13}{|l|}{ Panel A: Number of UI Spells } \\
\hline UPeriods $_{j} *$ Reform $_{t}$ & $\begin{array}{c}-0.0010 * * * \\
(0.0001)\end{array}$ & $\begin{array}{c}-0.0039 * * * \\
(0.0011)\end{array}$ & $\begin{array}{c}0.0005^{* * *} * \\
(0.0001)\end{array}$ & $\begin{array}{c}-0.0086 * * * \\
(0.0016)\end{array}$ & $\begin{array}{c}-0.0034 * * * \\
(0.0003)\end{array}$ & $\begin{array}{c}-0.0047 * * * * \\
(0.0010)\end{array}$ & $\begin{array}{c}0.0005 * * * \\
(0.0001)\end{array}$ & $\begin{array}{c}-0.0077 * * * \\
(0.0015)\end{array}$ & $\begin{array}{c}-0.0059 * * * \\
(0.0003)\end{array}$ & $\begin{array}{l}-0.0020^{*} \\
(0.0011)\end{array}$ & $\begin{array}{c}0.0001 * * * \\
(0.0000)\end{array}$ & $\begin{array}{c}-0.0083^{* * *} \\
(0.0016)\end{array}$ \\
\hline Affected $f_{j} *$ Reform $_{t}$ & $\begin{array}{c}-0.0059 * * * \\
(0.0006)\end{array}$ & $\begin{array}{l}-0.0025 \\
(0.0025)\end{array}$ & $\begin{array}{c}-0.0007 * * * \\
(0.0001)\end{array}$ & $\begin{array}{l}-0.0026 \\
(0.0034)\end{array}$ & $\begin{array}{c}-0.0064 * * * \\
(0.0006)\end{array}$ & $\begin{array}{l}-0.0038^{*} \\
(0.0023)\end{array}$ & $\begin{array}{c}-0.0008 * * * \\
(0.0001)\end{array}$ & $\begin{array}{c}0.0036 \\
(0.0032)\end{array}$ & $\begin{array}{c}-0.0017 * * * \\
(0.0006)\end{array}$ & $\begin{array}{c}-0.0053 * * \\
(0.0023)\end{array}$ & $\begin{array}{c}-0.0008 * * * \\
(0.0001)\end{array}$ & $\begin{array}{l}-0.0009 \\
(0.0034)\end{array}$ \\
\hline UPeriods $_{j} *$ Reform $_{t} *$ Risk $_{i}$ & $\begin{array}{c}0.0007 * * * \\
(0.0001)\end{array}$ & $\begin{array}{l}0.0004 * * \\
(0.0002)\end{array}$ & $\begin{array}{c}0.0001 * * * \\
(0.0000)\end{array}$ & $\begin{array}{l}0.0005^{*} \\
(0.0003)\end{array}$ & $\begin{array}{c}0.0014 * * * \\
(0.0001)\end{array}$ & $\begin{array}{c}0.0007 * * * \\
(0.0002)\end{array}$ & $\begin{array}{c}0.0001 * * * \\
(0.0000)\end{array}$ & $\begin{array}{c}0.0004 \\
(0.0003)\end{array}$ & $\begin{array}{c}0.0014 * * * \\
(0.0001)\end{array}$ & $\begin{array}{c}0.0001 \\
(0.0002)\end{array}$ & $\begin{array}{c}0.0001 * * * \\
(0.0000)\end{array}$ & $\begin{array}{l}0.0005^{*} \\
(0.0002)\end{array}$ \\
\hline Affected $_{j} *$ Reform $_{t} *$ Risk $_{i}$ & $\begin{array}{c}-0.0006^{* * * *} \\
(0.0001)\end{array}$ & $\begin{array}{c}0.0011 * * * \\
(0.0004)\end{array}$ & $\begin{array}{c}-0.0001 * * * \\
(0.0000)\end{array}$ & $\begin{array}{c}0.0021 * * * \\
(0.0005)\end{array}$ & $\begin{array}{c}-0.0006^{* * * *} \\
(0.0001)\end{array}$ & $\begin{array}{c}0.0015^{* * *} \\
(0.0004)\end{array}$ & $\begin{array}{c}-0.0001 * * * \\
(0.0000)\end{array}$ & $\begin{array}{l}0.0012^{* *} \\
(0.0006)\end{array}$ & $\begin{array}{c}-0.0012^{* * *} \\
(0.0001)\end{array}$ & $\begin{array}{c}0.0018^{* * *} \\
(0.0004)\end{array}$ & $\begin{array}{c}-0.0001 * * * \\
(0.0000)\end{array}$ & $\begin{array}{c}0.0018^{* * * *} \\
(0.0005)\end{array}$ \\
\hline $\begin{array}{l}\text { Firm*UPeriods FE } \\
\text { Firm*Month FE } \\
\text { Age Group*Month FE } \\
\text { Clustered SE }\end{array}$ & $\begin{array}{l}\text { yes } \\
\text { yes } \\
\text { yes } \\
\text { firm }\end{array}$ & $\begin{array}{l}\text { yes } \\
\text { yes } \\
\text { yes } \\
\text { firm }\end{array}$ & $\begin{array}{l}\text { yes } \\
\text { yes } \\
\text { yes } \\
\text { firm }\end{array}$ & $\begin{array}{l}\text { yes } \\
\text { yes } \\
\text { yes } \\
\text { firm }\end{array}$ & $\begin{array}{l}\text { yes } \\
\text { yes } \\
\text { yes } \\
\text { firm }\end{array}$ & $\begin{array}{l}\text { yes } \\
\text { yes } \\
\text { yes } \\
\text { firm }\end{array}$ & $\begin{array}{l}\text { yes } \\
\text { yes } \\
\text { yes } \\
\text { firm }\end{array}$ & $\begin{array}{l}\text { yes } \\
\text { yes } \\
\text { yes } \\
\text { firm }\end{array}$ & $\begin{array}{l}\text { yes } \\
\text { yes } \\
\text { yes } \\
\text { firm }\end{array}$ & $\begin{array}{l}\text { yes } \\
\text { yes } \\
\text { yes } \\
\text { firm }\end{array}$ & $\begin{array}{l}\text { yes } \\
\text { yes } \\
\text { yes } \\
\text { firm }\end{array}$ & $\begin{array}{l}\text { yes } \\
\text { yes } \\
\text { yes } \\
\text { firm }\end{array}$ \\
\hline $\begin{array}{l}\text { Observations } \\
R^{2}\end{array}$ & $\begin{array}{c}33,414,336 \\
0.536\end{array}$ & $\begin{array}{c}22,038,270 \\
0.760\end{array}$ & $\begin{array}{c}33,414,336 \\
0.256\end{array}$ & $\begin{array}{c}4,200,883 \\
0.545\end{array}$ & $\begin{array}{c}33,414,336 \\
0.536\end{array}$ & $\begin{array}{c}22,038,270 \\
0.689\end{array}$ & $\begin{array}{c}33,414,336 \\
0.256\end{array}$ & $\begin{array}{c}4,200,883 \\
0.545\end{array}$ & $\begin{array}{c}42,150,240 \\
0.536\end{array}$ & $\begin{array}{c}26,957,014 \\
0.699\end{array}$ & $\begin{array}{c}42,150,240 \\
0.249\end{array}$ & $\begin{array}{c}4,879,260 \\
0.555\end{array}$ \\
\hline \multicolumn{13}{|c|}{ Panel B: Macro-Economic Conditions } \\
\hline Affected ${ }_{j} *$ Crisis $_{t}$ & $\begin{array}{c}-0.0063 * * * \\
(0.0007)\end{array}$ & $\begin{array}{l}-0.0017 \\
(0.0016)\end{array}$ & $\begin{array}{l}-0.0182 \\
(0.0142)\end{array}$ & $\begin{array}{l}-0.0057 \\
(0.0039)\end{array}$ & $\begin{array}{c}-0.0057 * * * \\
(0.0005)\end{array}$ & $\begin{array}{l}-0.0023 * \\
(0.0013)\end{array}$ & $\begin{array}{l}-0.0132 \\
(0.0095)\end{array}$ & $\begin{array}{l}-0.0061 * \\
(0.0032)\end{array}$ & $\begin{array}{c}-0.0077 * * * \\
(0.0006)\end{array}$ & $\begin{array}{l}-0.0015 \\
(0.0013)\end{array}$ & $\begin{array}{l}-0.0104 \\
(0.0064)\end{array}$ & $\begin{array}{c}-0.0092 * * \\
(0.0036)\end{array}$ \\
\hline Affected $_{j} *$ Crisis $_{t} *$ Risk $_{i}$ & $\begin{array}{c}0.0001 \\
(0.0001)\end{array}$ & $\begin{array}{l}-0.0001 \\
(0.0002)\end{array}$ & $\begin{array}{c}0.0016 \\
(0.0019)\end{array}$ & $\begin{array}{l}-0.0003 \\
(0.0006)\end{array}$ & $\begin{array}{l}-0.0001 \\
(0.0001)\end{array}$ & $\begin{array}{c}0.0001 \\
(0.0002)\end{array}$ & $\begin{array}{l}0.0008 \\
(0.0014)\end{array}$ & $\begin{array}{l}-0.0003 \\
(0.0006)\end{array}$ & $\begin{array}{c}0.0001 \\
(0.0001)\end{array}$ & $\begin{array}{l}-0.0001 \\
(0.0002)\end{array}$ & $\begin{array}{c}0.0003 \\
(0.0007)\end{array}$ & $\begin{array}{c}0.0007 \\
(0.0005)\end{array}$ \\
\hline $\begin{array}{l}\text { Firm*Affected FE } \\
\text { Firm*Month FE } \\
\text { Age Group*Month FE } \\
\text { Clustered SE }\end{array}$ & $\begin{array}{l}\text { yes } \\
\text { yes } \\
\text { yes } \\
\text { firm }\end{array}$ & $\begin{array}{l}\text { yes } \\
\text { yes } \\
\text { yes } \\
\text { firm }\end{array}$ & $\begin{array}{l}\text { yes } \\
\text { yes } \\
\text { yes } \\
\text { firm }\end{array}$ & $\begin{array}{l}\text { yes } \\
\text { yes } \\
\text { yes } \\
\text { firm }\end{array}$ & $\begin{array}{l}\text { yes } \\
\text { yes } \\
\text { yes } \\
\text { firm }\end{array}$ & $\begin{array}{l}\text { yes } \\
\text { yes } \\
\text { yes } \\
\text { firm }\end{array}$ & $\begin{array}{l}\text { yes } \\
\text { yes } \\
\text { yes } \\
\text { firm }\end{array}$ & $\begin{array}{l}\text { yes } \\
\text { yes } \\
\text { yes } \\
\text { firm }\end{array}$ & $\begin{array}{l}\text { yes } \\
\text { yes } \\
\text { yes } \\
\text { firm }\end{array}$ & $\begin{array}{l}\text { yes } \\
\text { yes } \\
\text { yes } \\
\text { firm }\end{array}$ & $\begin{array}{l}\text { yes } \\
\text { yes } \\
\text { yes } \\
\text { firm }\end{array}$ & $\begin{array}{l}\text { yes } \\
\text { yes } \\
\text { yes } \\
\text { firm }\end{array}$ \\
\hline $\begin{array}{l}\text { Observations } \\
R^{2}\end{array}$ & $\begin{array}{c}4,864,752 \\
0.629\end{array}$ & $\begin{array}{l}3,957,554 \\
0.750\end{array}$ & $\begin{array}{c}4,864,752 \\
0.629\end{array}$ & $\begin{array}{c}1,146,378 \\
0.598\end{array}$ & $\begin{array}{c}4,864,752 \\
0.668\end{array}$ & $\begin{array}{c}3,957,554 \\
0.750\end{array}$ & $\begin{array}{c}4,864,752 \\
0.253\end{array}$ & $\begin{array}{c}1,146,378 \\
0.737\end{array}$ & $\begin{array}{c}7,128,864 \\
0.657\end{array}$ & $\begin{array}{c}5,682,407 \\
0.764\end{array}$ & $\begin{array}{c}7,128,864 \\
0.258\end{array}$ & $\begin{array}{c}1,555,991 \\
0.619\end{array}$ \\
\hline
\end{tabular}

This table reports changes in employment, wages, hiring, and hiring wages around the announcement of the reform. In Panel A, the sample is restricted to workers with one to four prior UI spells. In Panel B, the sample period covers the year before and after the onset of the global financial crisis. The variable Affected $d_{j}$ takes the value of one

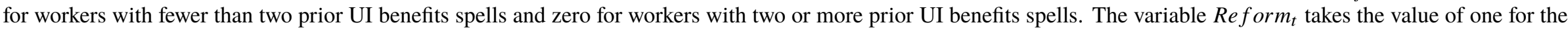
post-reform period from January 2015 to December 2016 and zero for the pre-reform period from January 2013 to December 2014 . The variable $C r i s i s_{t}$ takes the value of one for the crisis period from October 2008 to June 2009 and zero for the pre-crisis period from January 2008 to September 2008 . The variable Risk $k_{i}$ takes the values of one for the safest to ten for the riskiest decile of firms. The variable UPeriods $s_{j}$ is the number of UI benefits spells worker $j$ experienced. Standard errors are reported in parentheses. The bottom part of the table reports information on fixed effects and the clustering of standard errors. ***, **, and * denote statistical significance at the $1 \%$, $5 \%$, and $10 \%$ levels, respectively. 


\section{Table 7: Worker-Level Estimation}

\begin{tabular}{|c|c|c|c|c|}
\hline Risk Measure: & I & $\begin{array}{c}\text { Credit Spread } \\
\text { II } \\
\end{array}$ & $\begin{array}{c}\text { Default Provisions } \\
\text { III }\end{array}$ & $\begin{array}{c}\text { Layoff Risk } \\
\text { IV }\end{array}$ \\
\hline Dep. Var.: & \multicolumn{4}{|c|}{$\log \left(\right.$ wage $\left._{i}\right)$} \\
\hline Affected $_{j} *$ Reform $_{t}$ & $\begin{array}{c}0.0066 * * * \\
(0.0003)\end{array}$ & $\begin{array}{c}0.0037 * * \\
(0.0008)\end{array}$ & $\begin{array}{c}0.0046 * * * \\
(0.0008)\end{array}$ & $\begin{array}{l}-0.0001 \\
(0.0008)\end{array}$ \\
\hline Affected $_{j} * \operatorname{Reform}_{t} * \operatorname{Risk}_{i}$ & & $\begin{array}{c}0.0006^{* * * *} \\
(0.0002)\end{array}$ & $\begin{array}{c}0.0005^{* *} * \\
(0.0002)\end{array}$ & $\begin{array}{c}0.0012^{* * * *} \\
(0.0001)\end{array}$ \\
\hline $\begin{array}{l}\text { Firm-Time FE } \\
\text { Worker FE } \\
\text { Clustered SE }\end{array}$ & $\begin{array}{l}\text { yes } \\
\text { yes } \\
\text { firm }\end{array}$ & $\begin{array}{l}\text { yes } \\
\text { yes } \\
\text { firm }\end{array}$ & $\begin{array}{l}\text { yes } \\
\text { yes } \\
\text { firm }\end{array}$ & $\begin{array}{l}\text { yes } \\
\text { yes } \\
\text { firm }\end{array}$ \\
\hline $\begin{array}{l}\text { Observations } \\
R^{2}\end{array}$ & $\begin{array}{c}3,355,550 \\
0.987 \\
0.162\end{array}$ & $\begin{array}{c}2,903,434 \\
0.986 \\
0.167\end{array}$ & $\begin{array}{c}2,903,434 \\
0.986 \\
0.166\end{array}$ & $\begin{array}{c}3,355,550 \\
0.987 \\
0.263\end{array}$ \\
\hline
\end{tabular}

This table reports changes in wages at the worker level. Due to computational constraints, we select a 10 percent random sample of workers. The dependent variable is log wage. The variable Affected $d_{j}$ takes the value of one for workers with fewer than two prior UI benefits spells and zero for workers with two or more prior UI benefits spells. The variable Risk $k_{i}$ takes the values of one for the safest to ten for the riskiest decile

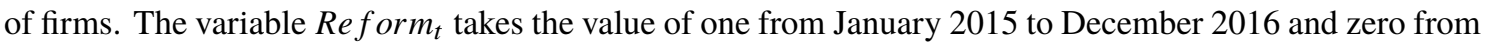
January 2013 to December 2014. Standard errors are reported in parentheses. The bottom part of the table reports information on fixed effects and the clustering of standard errors. $* * *, * *$, and $*$ denote statistical significance at the $1 \%, 5 \%$, and $10 \%$ levels, respectively. 
Table 8: Firm Risk and Natural Disasters

\begin{tabular}{|c|c|c|c|c|}
\hline \multirow[b]{2}{*}{ Dep. Var.: } & \multicolumn{2}{|c|}{ Employed Workers } & \multicolumn{2}{|c|}{ Hired Workers } \\
\hline & $\begin{array}{c}\text { ERate } \\
\text { I }\end{array}$ & $\begin{array}{c}\log (\text { wage }) \\
\text { II }\end{array}$ & $\begin{array}{c}\text { HiringRate } \\
\text { III }\end{array}$ & $\begin{array}{c}\log (\text { wage }) \\
\text { IV }\end{array}$ \\
\hline Affected $_{j} *$ Reform $_{t}$ & $\begin{array}{c}0.0585 * * \\
(0.0251)\end{array}$ & $\begin{array}{c}-0.0802 * * \\
(0.0373)\end{array}$ & $\begin{array}{c}0.0023 \\
(0.0016)\end{array}$ & $\begin{array}{l}-0.0909 * \\
(0.0481)\end{array}$ \\
\hline Affected $_{j} * \operatorname{Reform}_{t} * \operatorname{Risk}_{i}$ & $\begin{array}{c}-0.0218 * * * \\
(0.0045)\end{array}$ & $\begin{array}{c}0.0113 * * \\
(0.0050)\end{array}$ & $\begin{array}{c}-0.0008 * * * \\
(0.0003)\end{array}$ & $\begin{array}{c}0.0108 * * \\
(0.0052)\end{array}$ \\
\hline $\begin{array}{l}\text { Estimation } \\
\text { F-stat }\end{array}$ & $\begin{array}{l}\mathrm{IV} \\
35.01\end{array}$ & $\begin{array}{c}\mathrm{IV} \\
27.32\end{array}$ & $\begin{array}{l}\text { IV } \\
35.01\end{array}$ & $\begin{array}{l}\text { IV } \\
27.11\end{array}$ \\
\hline $\begin{array}{l}\text { Firm*Affected FE } \\
\text { Firm*Month FE } \\
\text { Age Group*Month FE } \\
\text { Clustered SE }\end{array}$ & $\begin{array}{l}\text { yes } \\
\text { yes } \\
\text { yes } \\
\text { firm }\end{array}$ & $\begin{array}{l}\text { yes } \\
\text { yes } \\
\text { yes } \\
\text { firm }\end{array}$ & $\begin{array}{l}\text { yes } \\
\text { yes } \\
\text { yes } \\
\text { firm }\end{array}$ & $\begin{array}{l}\text { yes } \\
\text { yes } \\
\text { yes } \\
\text { firm }\end{array}$ \\
\hline $\begin{array}{l}\text { Observations } \\
R^{2}\end{array}$ & $\begin{array}{c}21,280,320 \\
0.520\end{array}$ & $\begin{array}{c}17,144,583 \\
0.768\end{array}$ & $\begin{array}{c}21,280,320 \\
0.414\end{array}$ & $\begin{array}{c}4,696,198 \\
0.718\end{array}$ \\
\hline
\end{tabular}

This table reports changes in employment, wages, hiring, and hiring wages around the announcement of the reform based on the instrumental variable strategy described in equation (8). The dependent variable is the employment of workers affected or unaffected by the reform by firm $i$ in month $t$ over total employment in December 2014 in column I, the log average wage in column II, the number of workers hired relative to a firm's employment in December 2014 in column III, and the log average hiring wage in column IV. The variable $A$ f $_{\text {ected }}$ takes the value of one for workers with fewer than two prior UI benefits spells and zero

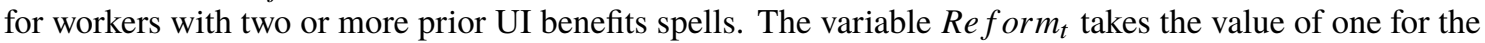
post-reform period from January 2015 to December 2016 and zero for the pre-reform period from January 2013 to December 2014. The variable Risk $k_{i}$ takes the values of one for the safest to ten for the riskiest decile of firms. Standard errors are reported in parentheses. The bottom part of the table reports information on fixed effects and the clustering of standard errors. ***, **, and * denote statistical significance at the $1 \%$, $5 \%$, and $10 \%$ levels, respectively.

Table 9: Firm Value

\begin{tabular}{|c|c|c|c|c|c|c|c|c|c|}
\hline Dep. Var.: $C A R[-1 ;+3]$ & I & II & III & IV & $\mathrm{V}$ & VI & VII & VIII & IX \\
\hline Risk Measure: & \multicolumn{3}{|c|}{ Credit Spread } & \multicolumn{3}{|c|}{ Default Provisions } & \multicolumn{3}{|c|}{ Layoff Risk } \\
\hline$R_{i s k_{i}}$ & $\begin{array}{c}-1.72 * * * \\
(0.48)\end{array}$ & $\begin{array}{c}-1.72 * * \\
(0.54)\end{array}$ & $\begin{array}{c}-2.02 * * \\
(0.69)\end{array}$ & $\begin{array}{l}-1.19 \\
(0.93)\end{array}$ & $\begin{array}{l}-1.23 \\
(0.86)\end{array}$ & $\begin{array}{c}-2.35 * * \\
(0.95)\end{array}$ & $\begin{array}{c}-1.83 * * * \\
(0.52)\end{array}$ & $\begin{array}{c}-2.07 * * * * \\
(0.62)\end{array}$ & $\begin{array}{c}-2.38 * * \\
(0.85)\end{array}$ \\
\hline Clustered SE & ind & ind & ind & ind & ind & ind & ind & ind & ind \\
\hline Observations & 140 & 127 & 111 & 140 & 127 & 111 & 155 & 140 & 121 \\
\hline$R^{2}$ & 0.031 & 0.031 & 0.042 & 0.012 & 0.013 & 0.044 & 0.028 & 0.036 & 0.046 \\
\hline
\end{tabular}

This table reports cumulative abnormal returns in the 5 days around the announcement of the reform on December 29, 2014. The sample consists of all listed firms in Brazil with at least 50 (columns I, IV, and VII), 100 (columns II, V, and VIII), or 200 (columns III, VI, and IX) trading days during 2014. The variable Risk $k_{i}$ takes the value one for firms with above-median levels of risk and zero for below-median firms. Standard errors are reported in parentheses. $* * *$ and $* *$ denote statistical significance at the $1 \%$ and $5 \%$ levels, respectively. 
Table 10: Entrepreneurship

\begin{tabular}{|c|c|c|c|c|}
\hline \multirow[t]{2}{*}{ Dep. Var.: } & $\log$ (business formation) & $\Delta$ wage & $\mathrm{P}[$ closure $12 \mathrm{~m}]$ & $\mathrm{P}[$ loan $12 \mathrm{~m}]$ \\
\hline & I & II & III & IV \\
\hline \multicolumn{5}{|c|}{ Panel A: Affected vs Unaffected Workers } \\
\hline Affected $_{j} *$ Reform $_{t}$ & $\begin{array}{c}0.0338 * * * \\
(0.0031)\end{array}$ & $\begin{array}{c}0.0030 \\
(0.0040)\end{array}$ & $\begin{array}{c}0.0043 * * * \\
(0.0006)\end{array}$ & $\begin{array}{c}-0.0029 * * * \\
(0.0007)\end{array}$ \\
\hline $\begin{array}{l}\text { Municipality-Affected FE } \\
\text { Month-Municipality FE } \\
\text { Clustered SE }\end{array}$ & $\begin{array}{l}\text { yes } \\
\text { yes } \\
\text { muni }\end{array}$ & $\begin{array}{l}\text { yes } \\
\text { yes } \\
\text { muni }\end{array}$ & $\begin{array}{l}\text { yes } \\
\text { yes } \\
\text { muni }\end{array}$ & $\begin{array}{c}\text { yes } \\
\text { yes } \\
\text { muni }\end{array}$ \\
\hline $\begin{array}{l}\text { Observations } \\
R^{2}\end{array}$ & $\begin{array}{c}376,953 \\
0.843\end{array}$ & $\begin{array}{c}135,506 \\
0.171\end{array}$ & $\begin{array}{c}376,953 \\
0.138\end{array}$ & $\begin{array}{c}376,953 \\
0.245\end{array}$ \\
\hline \multicolumn{5}{|c|}{ Panel B: Share of Affected Worker } \\
\hline$\%$ Affected f $_{m} *$ Reform $_{t}$ & $\begin{array}{c}-0.1212 * * * \\
(0.0338)\end{array}$ & $\begin{array}{c}0.0426^{* *} \\
(0.0176)\end{array}$ & $\begin{array}{c}-0.0375 * * * \\
(0.0094)\end{array}$ & $\begin{array}{c}0.0419 * * * \\
(0.0096)\end{array}$ \\
\hline $\begin{array}{l}\text { Municipality FE } \\
\text { Month-Mesoregion FE } \\
\text { Clustered SE }\end{array}$ & $\begin{array}{l}\text { yes } \\
\text { yes } \\
\text { muni }\end{array}$ & $\begin{array}{l}\text { yes } \\
\text { yes } \\
\text { muni }\end{array}$ & $\begin{array}{l}\text { yes } \\
\text { yes } \\
\text { muni }\end{array}$ & $\begin{array}{l}\text { yes } \\
\text { yes } \\
\text { muni }\end{array}$ \\
\hline $\begin{array}{l}\text { Observations } \\
R^{2}\end{array}$ & $\begin{array}{c}228,689 \\
0.877\end{array}$ & $\begin{array}{c}100,964 \\
0.156\end{array}$ & $\begin{array}{c}228,689 \\
0.076\end{array}$ & $\begin{array}{c}228,689 \\
0.191\end{array}$ \\
\hline
\end{tabular}

This table examines changes in new business formation and quality around the reform. The dependent variable is the log number of new businesses formed in a given month (column I), the change in wages for workers hired by new firms relative to their last prior wage (column II), the probability of a new business closing within 12 months (column III), and the probability of a business taking out a loan within 12 months (column IV). In Panel A, we aggregate dependent variables at the municipality-worker group level, in Panel B we aggregate dependent variables at the municipality level. Af fected takes the value of one for workers affected by the reform and zero for workers unaffected by the reform. \%Affected $d_{m}$ is the fraction of working-age population in a municipality that is affected by the reform. The variable $\operatorname{Reform}_{t}$ takes the value of one for the post-reform period from January 2015 to December 2016 and zero for the pre-reform period from January 2013 to December 2014. The bottom part reports information on fixed effects and the clustering of standard errors. $* * *$ and $* *$ denote statistical significance at the $1 \%$ and $5 \%$ levels, respectively. 


\section{Appendix A. Summary of Labor Laws}

In this section, we summarize the changes in the Labor Law that define a worker's eligibility for unemployment benefits. The eligibility is defined in Article 3 of the original labor law 7998, which was enacted on January 11, 1990. This eligibility was updated by the provisional measure 665 which was first announced on December 29, 2014 and came into effect on March 1, 2015. ${ }^{24}$ Finally, the provisional measure was transformed into law 13 135 on June 16, 2015 and has been in effect since July 1, 2015. In what follows next, we provide the relevant part of each law defining a worker's eligibility for UI benefits, the source of the law, the wording of the law in Portuguese, and the English translation.

\section{Law 7998, in effect from January 11, 1990 until March 1, 2015}

Source: http://wWW .planalto.gov.br/ccivil_03/LEIS/L7998.htm

Portuguese [definition of eligibility]:

Art. $3^{\text {o }}$ Terá direito à percepção do seguro-desemprego o trabalhador dispensado sem justa causa que comprove:

I - ter recebido salários de pessoa jurídica ou pessoa física a ela equiparada, relativos a cada um dos 6 (seis) meses imediatamente anteriores à data da dispensa;

English [definition of eligibility]:

Art. 3 A worker dismissed without just cause shall have the right to claim unemployment insurance if the following is satisfied:

I-The worker has received salaries from a firm or an individual equivalent to it for each of the six (6) months immediately preceding the date of the dismissal;

\section{Provisional Measure MPV 665; Announced December 29, 2014. In effect between March 1, 2015 and July 1, 2015}

Source: http: //www.planalto.gov.br/ccivil_03/_Ato2011-2014/2014/Mpv/mpv665. htm

Portuguese [definition of eligibility]:

\footnotetext{
${ }^{24}$ The reform was officially published by the Federal Government on December 30, 2014, while the newspapers discussed it already on December 29, 2014.
} 
Art. $3^{o}$ Terá direito à percepção do seguro-desemprego o trabalhador dispensado sem justa causa que comprove:

I - ter recebido salários de pessoa jurídica ou pessoa física a ela equiparada, relativos:

a) a pelo menos dezoito meses nos últimos vinte e quatro meses imediatamente anteriores à data da dispensa, quando da primeira solicitação;

b) a pelo menos doze meses nos últimos dezesseis meses imediatamente anteriores à data da dispensa, quando da segunda solicitação; $e$

c) a cada um dos seis meses imediatamente anteriores à data da dispensa quando das demais solicitações;

English [definition of eligibility]:

Art. 3 A worker dismissed without just cause shall have the right to claim unemployment insurance if the following is satisfied:

I-The worker has received salaries from a firm or an individual equivalent to it:

a) for at least eighteen months in the last twenty-four months immediately preceding the date of dismissal at the time of the first request;

b) for at least twelve months in the last sixteen months immediately preceding the date of dismissal at the time of the second request; and

c) for each one of the six months immediately preceding the date of the dismissal at the time of the third or higher request;

\section{Law 13 134; Enacted June 16, 2015. In effect from July 1, 2015}

Source: http: //www.planalto.gov.br/ccivil_03/_Ato2015-2018/2015/Lei/L13134. htm

Portuguese [definition of eligibility]:

Art. $3^{o}$ Terá direito à percepção do seguro-desemprego o trabalhador dispensado sem justa causa que comprove:

I - ter recebido salários de pessoa jurídica ou de pessoa física a ela equiparada, relativos a:

a) pelo menos 12 (doze) meses nos últimos 18 (dezoito) meses imediatamente anteriores à data de dispensa, quando da primeira solicitação;

b) pelo menos 9 (nove) meses nos últimos 12 (doze) meses imediatamente anteriores à data de dispensa, quando da segunda solicitação; $e$

c) cada um dos 6 (seis) meses imediatamente anteriores à data de dispensa, quando das demais solicitações; 
English [definition of eligibility]:

Art. 3 A worker dismissed without just cause shall have the right to claim unemployment insurance if the following is satisfied:

I-The worker has received salaries from a firm or an individual equivalent to it:

a) for at least 12 (twelve) months in the last 18 (eighteen) months immediately preceding the date of the dismissal at the time of the first request;

b) for at least 9 (nine) months in the last 12 (twelve) months immediately preceding the date of the dismissal at the time of the second request; and

c) for each of the six (6) months immediately preceding the date of the dismissal at the time of the third or higher request; 


\section{Appendix B. Additional Tables}

Table A.1: Aggregate Employment Effects

\begin{tabular}{|c|c|c|c|}
\hline Risk Measure: & Credit Spread & Default Provisions & Layoff Risk \\
\hline${\text { Dep. Var.: } \text { ERate }_{i}}$ & $\mathrm{I}$ & II & III \\
\hline $\operatorname{Reform}_{t} * \operatorname{Risk}_{i}$ & $\begin{array}{c}-0.0031 * * * * \\
(0.0006)\end{array}$ & $\begin{array}{c}-0.0050 * * * \\
(0.0006)\end{array}$ & $\begin{array}{c}-0.0047 * * * \\
(0.0006)\end{array}$ \\
\hline $\begin{array}{l}\text { Firm FE } \\
\text { Month*Muni*Industry FE } \\
\text { Clustered SE }\end{array}$ & $\begin{array}{l}\text { yes } \\
\text { yes } \\
\text { firm }\end{array}$ & $\begin{array}{l}\text { yes } \\
\text { yes } \\
\text { firm }\end{array}$ & $\begin{array}{l}\text { yes } \\
\text { yes } \\
\text { firm }\end{array}$ \\
\hline $\begin{array}{l}\text { Observations } \\
R^{2}\end{array}$ & $\begin{array}{c}1,132,655 \\
0.265\end{array}$ & $\begin{array}{c}1,132,655 \\
0.265\end{array}$ & $\begin{array}{c}1,432,815 \\
0.289\end{array}$ \\
\hline
\end{tabular}

This table reports firm-level changes in total firm-level employment around the reform. The dependent variable is total employment of firm $i$ in month $t$ over total employment in December 2014. The variable Reform $_{t}$ takes the value of one for the post-reform period from January 2015 to December 2016 and zero for the pre-reform period from January 2013 to December 2014. The variable Risk $k_{i}$ takes the values of one for the safest up to ten for the riskiest decile of firms. Standard errors are reported in parentheses. The bottom part of the table reports information on fixed effects and the clustering of standard errors. *** denotes statistical significance at the $1 \%$ level. 
Table A.2: Firm Risk and Natural Disasters

\begin{tabular}{|c|c|c|}
\hline \multirow[t]{3}{*}{ Dep. Var.: } & \multicolumn{2}{|c|}{ Layoff Risk } \\
\hline & \multicolumn{2}{|c|}{ Pre-Reform Post-Reform } \\
\hline & I & II \\
\hline Shock $_{i}$ & $\begin{array}{c}2.2283 * * * \\
(0.2736)\end{array}$ & $\begin{array}{c}1.9979 * * * \\
(0.3515)\end{array}$ \\
\hline Exposure $_{i}$ & $\begin{array}{c}0.4831 * * * \\
(0.23218)\end{array}$ & $\begin{array}{c}0.9605 * * * \\
(0.2674)\end{array}$ \\
\hline Shock Size $_{i}$ & $\begin{array}{c}-0.3652 * * * \\
(0.0484)\end{array}$ & $\begin{array}{c}-0.3386 * * * \\
(0.0617)\end{array}$ \\
\hline $\log (\text { employees })_{i}$ & $\begin{array}{c}0.0369 \\
(0.0307) \\
\end{array}$ & $\begin{array}{c}0.0222 \\
(0.0228)\end{array}$ \\
\hline $\begin{array}{l}\text { Municipality FE } \\
\text { Clustered SE }\end{array}$ & $\begin{array}{l}\text { yes } \\
\text { muni }\end{array}$ & $\begin{array}{l}\text { yes } \\
\text { muni }\end{array}$ \\
\hline $\begin{array}{l}\text { Observations } \\
\text { F-stat }\end{array}$ & $\begin{array}{c}36,158 \\
20.12\end{array}$ & $\begin{array}{r}36,158 \\
19.07\end{array}$ \\
\hline$R^{2}$ & 0.106 & 0.093 \\
\hline
\end{tabular}

This table reports the predicted level of firm risk based on our IV estimation (equation (8)). The dependent variable in column I is the probability of being laid off within 12 months after being hired, measured in the 2 years before the reform (2013-2014). In column II, the dependent variable is the probability of being laid off within 12 months after being hired, measured in the 2 years after the reform (2015-2016). Both variables sort firms into deciles based on layoff risk. The independent variable $S h o c k_{i}$ equals one if firm $i$ was connected to a supplier that was affected by a natural disaster during 2013 to 2014, Exposure $_{i}$ measures a firm's exposure to the natural disaster as the fraction of the firm's cash flows that goes to affected suppliers, Shock Size $e_{i}$ measures the size of the shock as the log of the sum of private and public damage in the affected municipality, and $\log (\text { employees })_{i}$ is the $\log$ of the number of employees of a firm at the end of 2014. Standard errors are reported in parentheses. The bottom part of the table reports information on fixed effects and the clustering of standard errors. ${ }^{* * *}$ denotes statistical significance at the $1 \%$ level. 
Table A.3: Occupations

\begin{tabular}{|c|c|c|c|c|}
\hline \multirow[b]{2}{*}{ Dep. Var.: } & \multicolumn{2}{|c|}{ Employed Workers } & \multicolumn{2}{|c|}{ Hired Workers } \\
\hline & $\begin{array}{c}\text { ERate } \\
\text { I }\end{array}$ & $\begin{array}{c}\log (\text { wage }) \\
\text { II }\end{array}$ & $\begin{array}{c}\text { Hiring Rate } \\
\text { III }\end{array}$ & $\begin{array}{c}\log (\text { wage }) \\
\text { IV }\end{array}$ \\
\hline Affected $_{i j o} *$ Reform $_{t}$ & $\begin{array}{c}0.0002 \\
(0.0006)\end{array}$ & $\begin{array}{l}-0.0017 \\
(0.0012)\end{array}$ & $\begin{array}{c}-0.0015^{* * * *} \\
(0.0001)\end{array}$ & $\begin{array}{c}0.0089 * * * \\
(0.0020)\end{array}$ \\
\hline $\begin{array}{l}\text { Affected } \text { Iijo } * \text { Reform }_{t} \\
\quad * \text { Occupation Layoff Risk }_{i o}\end{array}$ & $\begin{array}{c}-0.0041 * * * \\
(0.0001)\end{array}$ & $\begin{array}{l}0.0020 * * * \\
(0.0002)\end{array}$ & $\begin{array}{c}-0.0002 * * * \\
(0.0001)\end{array}$ & $\begin{array}{c}0.0009 * * * \\
(0.0003)\end{array}$ \\
\hline $\begin{array}{l}\text { Firm*Affected*Occupation FE } \\
\text { Firm*Occupation*Month FE } \\
\text { Age Group*Oocupation*Month FE } \\
\text { Clustered SE }\end{array}$ & $\begin{array}{l}\text { yes } \\
\text { yes } \\
\text { yes } \\
\text { firm }\end{array}$ & $\begin{array}{l}\text { yes } \\
\text { yes } \\
\text { yes } \\
\text { firm }\end{array}$ & $\begin{array}{l}\text { yes } \\
\text { yes } \\
\text { yes } \\
\text { firm }\end{array}$ & $\begin{array}{l}\text { yes } \\
\text { yes } \\
\text { yes } \\
\text { firm }\end{array}$ \\
\hline $\begin{array}{l}\text { Observations } \\
R^{2}\end{array}$ & $\begin{array}{l}39,701,952 \\
0.474\end{array}$ & $\begin{array}{c}26,985,527 \\
0.807\end{array}$ & $\begin{array}{l}39,701,952 \\
0.362\end{array}$ & $\begin{array}{c}5,415,273 \\
0.720\end{array}$ \\
\hline
\end{tabular}

This table reports changes in employment, wages, hiring, and hiring wages around the reform. The dependent variable is the employment of workers affected or unaffected by the reform by firm $i$ in month $t$ over total employment in December 2014 in column I, the log average wage in column II, the number of workers hired relative to a firm's employment in December 2014 in column III, and the log average hiring wage in column

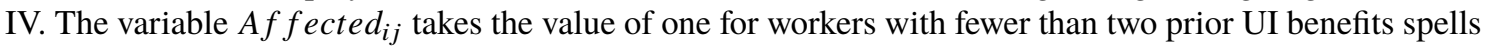
and zero for workers with two or more prior UI benefits spells. The variable Re form $t$ takes the value of one for the post-reform period from January 2015 to December 2016 and zero for the pre-reform period from January 2013 to December 2014. The variable Occupation Layoff Risk $k_{i o}$ takes the values of one for the safest to ten for the riskiest decile of firm-occupation pairs. Standard errors are reported in parentheses. The bottom part of the table reports information on fixed effects and the clustering of standard errors. *** denotes statistical significance at the $1 \%$ level. 
Table A.4: Tenure-Wage Profiles

\begin{tabular}{|c|c|c|c|c|}
\hline \multicolumn{2}{|l|}{ Risk Measure: } & \multirow{2}{*}{$\frac{\text { Credit Spread }}{\text { II }}$} & \multirow{2}{*}{$\frac{\text { Default Provisions }}{\text { III }}$} & \multirow{2}{*}{$\frac{\text { Layoff Risk }}{\text { IV }}$} \\
\hline Dep. Var.: wage growt $h_{i j t}^{e}$ & I & & & \\
\hline \multicolumn{5}{|l|}{ Panel A: Existing Employees } \\
\hline Affected $_{i j} *$ Reform $_{t}$ & $\begin{array}{l}0.0069 * * * \\
(0.0002)\end{array}$ & $\begin{array}{l}-0.0028 * * * \\
(0.0006)\end{array}$ & $\begin{array}{c}-0.0017 * * * \\
(0.0005)\end{array}$ & $\begin{array}{c}-0.0096 * * * \\
(0.0006)\end{array}$ \\
\hline Affected $i j *$ Reform $_{t} * \operatorname{Risk}_{i}$ & & $\begin{array}{c}0.0016^{* * * *} \\
(0.0001)\end{array}$ & $\begin{array}{c}0.0016^{* * * *} \\
(0.0001)\end{array}$ & $\begin{array}{c}0.0028 * * * \\
(0.0001)\end{array}$ \\
\hline $\begin{array}{l}\text { Firm*Affected FE } \\
\text { Firm*Month FE } \\
\text { Age Group*Month FE } \\
\text { Clustered SE }\end{array}$ & $\begin{array}{l}\text { yes } \\
\text { yes } \\
\text { yes } \\
\text { firm }\end{array}$ & $\begin{array}{l}\text { yes } \\
\text { yes } \\
\text { yes } \\
\text { firm }\end{array}$ & $\begin{array}{l}\text { yes } \\
\text { yes } \\
\text { yes } \\
\text { firm }\end{array}$ & $\begin{array}{l}\text { yes } \\
\text { yes } \\
\text { yes } \\
\text { firm }\end{array}$ \\
\hline $\begin{array}{l}\text { Observations } \\
R^{2}\end{array}$ & $\begin{array}{l}13,695,842 \\
0.451\end{array}$ & $\begin{array}{c}11,090,833 \\
0.436\end{array}$ & $\begin{array}{c}11,090,833 \\
0.436\end{array}$ & $\begin{array}{c}13,695,842 \\
0.452\end{array}$ \\
\hline \multicolumn{5}{|l|}{ Panel B: New Hires } \\
\hline Affected $_{i j} *$ Reform $_{t}$ & $\begin{array}{c}0.0056 * * * \\
(0.0007)\end{array}$ & $\begin{array}{c}0.0016 \\
(0.0016)\end{array}$ & $\begin{array}{l}0.0028^{*} \\
(0.0015)\end{array}$ & $\begin{array}{c}0.0010 \\
(0.0016)\end{array}$ \\
\hline Affected $_{i j} *$ Reform $_{t} *$ Risk $_{i}$ & & $\begin{array}{c}0.0007 * * * \\
(0.0003)\end{array}$ & $\begin{array}{l}0.0005^{* *} \\
(0.0004)\end{array}$ & $\begin{array}{c}0.0008 * * * \\
(0.0002)\end{array}$ \\
\hline $\begin{array}{l}\text { Firm*Affected FE } \\
\text { Firm*Month FE } \\
\text { Age Group*Month FE } \\
\text { Clustered SE }\end{array}$ & $\begin{array}{l}\text { yes } \\
\text { yes } \\
\text { yes } \\
\text { firm }\end{array}$ & $\begin{array}{l}\text { yes } \\
\text { yes } \\
\text { yes } \\
\text { firm }\end{array}$ & $\begin{array}{l}\text { yes } \\
\text { yes } \\
\text { yes } \\
\text { firm }\end{array}$ & $\begin{array}{l}\text { yes } \\
\text { yes } \\
\text { yes } \\
\text { firm }\end{array}$ \\
\hline $\begin{array}{l}\text { Observations } \\
R^{2}\end{array}$ & $\begin{array}{c}4,661,610 \\
0.260\end{array}$ & $\begin{array}{c}3,962,864 \\
0.258\end{array}$ & $\begin{array}{c}3,962,864 \\
0.709\end{array}$ & $\begin{array}{c}4,661,610 \\
0.260\end{array}$ \\
\hline
\end{tabular}

This table reports changes in excess wage growth for current (Panel A) and newly hired (Panel B) workers around the reform. The dependent variable (wage growt $h_{i j t}^{e}$ ) is the excess wage growth for workers of firm $i$ in group $j$ in month $t$. In Panel A, excess wage is computed as wage over the wage predicted based on average wage growth of workers with the same tenure. In Panel B, excess wage growth is computed as wage growth relative to the previous job over the predicted wage growth based on a worker's tenure at their last job. The variable $A f$ fected $_{i j}$ takes the value of one for workers with fewer than two prior UI benefits spells and zero for workers with two or more prior UI benefits spells. The variable $\operatorname{Reform}_{t}$ takes the value of one for the post-reform period from January 2015 to December 2016 and zero for the pre-reform period from January 2013 to December 2014. The variable Risk $k_{i}$ takes the values of one for the safest to ten for the riskiest decile of firms. Standard errors are reported in parentheses. The bottom part of the table reports information on fixed effects and the clustering of standard errors. $* * *, * *$, and $*$ denote statistical significance at the $1 \%, 5 \%$, and $10 \%$ levels, respectively. 
Table A.5: Tenure Control

\begin{tabular}{|c|c|c|c|c|}
\hline \multirow[b]{2}{*}{ Dep. Var.: } & \multicolumn{2}{|c|}{ Employed Workers } & \multicolumn{2}{|c|}{ Hired Workers } \\
\hline & $\begin{array}{c}\text { ERate } \\
\text { I }\end{array}$ & $\begin{array}{c}\log (\text { wage }) \\
\text { II }\end{array}$ & $\begin{array}{c}\text { Hiring Rate } \\
\text { III }\end{array}$ & $\begin{array}{c}\log (\text { wage }) \\
\text { IV }\end{array}$ \\
\hline \multicolumn{5}{|l|}{ Panel A: Credit Spread } \\
\hline Affected $i j *$ Reform $_{t}$ & $\begin{array}{c}-0.0228 * * * \\
(0.0026)\end{array}$ & $\begin{array}{c}-0.0405 * * * \\
(0.0049)\end{array}$ & $\begin{array}{c}-0.0017 * * * \\
(0.0001)\end{array}$ & $\begin{array}{c}0.0150 * * * \\
(0.0029)\end{array}$ \\
\hline Affected $_{i j} *$ Reform $_{t} *$ Risk $_{i}$ & $\begin{array}{c}-0.0009 * * * \\
(0.0003)\end{array}$ & $\begin{array}{c}0.0013 * * * \\
(0.0003)\end{array}$ & $\begin{array}{c}-0.0002 * * * \\
(0.0000)\end{array}$ & $\begin{array}{c}0.0010 * * * \\
(0.0003)\end{array}$ \\
\hline $\begin{array}{l}\text { Observations } \\
R^{2}\end{array}$ & $\begin{array}{c}16,766,784 \\
0.498\end{array}$ & $\begin{array}{c}13,835,418 \\
0.736\end{array}$ & $\begin{array}{c}16,766,784 \\
0.478\end{array}$ & $\begin{array}{c}3,996,047 \\
0.597\end{array}$ \\
\hline \multicolumn{5}{|l|}{ Panel B: Default Provisions } \\
\hline Affected $i j *$ Reform $_{t}$ & $\begin{array}{c}-0.0175 * * * \\
(0.0024)\end{array}$ & $\begin{array}{c}-0.0388 * * * \\
(0.0048)\end{array}$ & $\begin{array}{c}-0.0023 * * * \\
(0.0001)\end{array}$ & $\begin{array}{c}0.0167 * * \\
(0.0027)\end{array}$ \\
\hline Affected $_{i j} *$ Reform $_{t} * \operatorname{Risk}_{i}$ & $\begin{array}{c}-0.0022 * * * \\
(0.0003)\end{array}$ & $\begin{array}{c}0.0009 * * * \\
(0.0003)\end{array}$ & $\begin{array}{c}-0.0001 * * * \\
(0.0000)\end{array}$ & $\begin{array}{c}0.0009 * * \\
(0.0006)\end{array}$ \\
\hline $\begin{array}{l}\text { Observations } \\
R^{2}\end{array}$ & $\begin{array}{c}16,766,784 \\
0.497\end{array}$ & $\begin{array}{c}13,835,418 \\
0.736\end{array}$ & $\begin{array}{c}16,766,784 \\
0.478\end{array}$ & $\begin{array}{c}3,996,047 \\
0.597\end{array}$ \\
\hline \multicolumn{5}{|l|}{ Panel C: Layoff Risk } \\
\hline Affected f $_{i j} *$ Reform $_{t}$ & $\begin{array}{c}-0.0171 * * * \\
(0.0028)\end{array}$ & $\begin{array}{c}-0.0536 * * * \\
(0.0047)\end{array}$ & $\begin{array}{c}-0.0021 * * * \\
(0.0001)\end{array}$ & $\begin{array}{c}0.0124 * * * \\
(0.0028)\end{array}$ \\
\hline Affected $_{i j} * \operatorname{Reform}_{t} * \operatorname{Risk}_{i}$ & $\begin{array}{c}-0.0017 * * * \\
(0.0003)\end{array}$ & $\begin{array}{c}0.0029 * * * \\
(0.0003)\end{array}$ & $\begin{array}{c}-0.0001 * * * \\
(0.0000)\end{array}$ & $\begin{array}{c}0.0014 * * * \\
(0.0003)\end{array}$ \\
\hline $\begin{array}{l}\text { Firm*Affected FE } \\
\text { Firm*Month FE } \\
\text { Age Group*Month FE } \\
\text { Tenure Controls } \\
\text { Clustered SE }\end{array}$ & $\begin{array}{l}\text { yes } \\
\text { yes } \\
\text { yes } \\
\text { yes } \\
\text { firm }\end{array}$ & $\begin{array}{l}\text { yes } \\
\text { yes } \\
\text { yes } \\
\text { yes } \\
\text { firm }\end{array}$ & $\begin{array}{c}\text { yes } \\
\text { yes } \\
\text { yes } \\
\text { yes } \\
\text { firm }\end{array}$ & $\begin{array}{l}\text { yes } \\
\text { yes } \\
\text { yes } \\
\text { yes } \\
\text { firm }\end{array}$ \\
\hline $\begin{array}{l}\text { Observations } \\
R^{2}\end{array}$ & $\begin{array}{c}21,280,320 \\
0.476\end{array}$ & $\begin{array}{c}17,144,583 \\
0.745\end{array}$ & $\begin{array}{c}21,280,320 \\
0.477\end{array}$ & $\begin{array}{c}4,696,198 \\
0.607\end{array}$ \\
\hline
\end{tabular}

This table reports changes in employment and wages around the reform. The dependent variable is the employment of workers affected or unaffected by the reform by firm $i$ in month $t$ over total employment in December 2014 in column I, the log average wage in column II, the number of workers hired relative to a firm's employment in December 2014 in column III, and the log average hiring wage in column IV. The

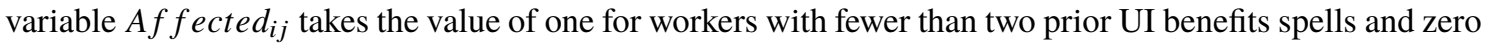
for workers with two or more prior UI benefits spells. The variable Re form $t$ takes the value of one for the post-reform period from January 2015 to December 2016 and zero for the pre-reform period from January 2013 to December 2014. Standard errors are reported in parentheses. The bottom part of the table reports information on fixed effects and the clustering of standard errors. *** and ** denote statistical significance at the $1 \%$ and $5 \%$ levels, respectively. 
Table A.6: Municipality Informality

\begin{tabular}{|c|c|c|c|c|c|c|c|c|}
\hline \multirow{4}{*}{ Dep. Var.: } & \multicolumn{4}{|c|}{ High Informality } & \multicolumn{4}{|c|}{ Low Informality } \\
\hline & \multicolumn{2}{|c|}{ Employed Workers } & \multicolumn{2}{|c|}{ Hired Workers } & \multicolumn{2}{|c|}{ Employed Workers } & \multicolumn{2}{|c|}{ Hired Workers } \\
\hline & ERate & $\log ($ wage $)$ & HiringRate & $\log (w a g e)$ & ERate & $\log (w a g e)$ & HiringRate & $\log ($ wage $)$ \\
\hline & I & II & III & IV & $\mathrm{V}$ & VI & VII & VIII \\
\hline \multicolumn{9}{|l|}{ Panel A: Credit Spread } \\
\hline Affected $_{i j} * \operatorname{Reform}_{t} * \operatorname{Risk}_{i}$ & $\begin{array}{c}-0.0026 * * * \\
(0.0004)\end{array}$ & $\begin{array}{c}0.0007 * * \\
(0.0003)\end{array}$ & $\begin{array}{c}-0.0003 * * * \\
(0.0000)\end{array}$ & $\begin{array}{c}0.0013 * * * \\
(0.0004)\end{array}$ & $\begin{array}{c}-0.0027 * * * \\
(0.0004)\end{array}$ & $\begin{array}{c}0.0010 * * * \\
(0.0003)\end{array}$ & $\begin{array}{c}-0.0002 * * * \\
(0.0000)\end{array}$ & $\begin{array}{c}0.0009 * * \\
(0.0003)\end{array}$ \\
\hline Observations & $7,735,104$ & $6,280,801$ & $7,735,104$ & $1,652,425$ & $9,031,680$ & $7,554,617$ & $9,031,680$ & $2,343,622$ \\
\hline$R^{2}$ & 0.504 & 0.727 & 0.369 & 0.555 & 0.499 & 0.773 & 0.365 & 0.606 \\
\hline \multicolumn{9}{|l|}{ Panel B: Default Provisions } \\
\hline Affected $i j * \operatorname{Reform}_{t} * \operatorname{Risk}_{i}$ & $\begin{array}{c}-0.0044 * * * \\
(0.0004)\end{array}$ & $\begin{array}{c}0.0015 * * * \\
(0.0004)\end{array}$ & $\begin{array}{c}-0.0001 * * * \\
(0.0000)\end{array}$ & $\begin{array}{l}0.0008 * \\
(0.0005)\end{array}$ & $\begin{array}{c}-0.0036 * * * \\
(0.0004)\end{array}$ & $\begin{array}{c}0.0007 * * \\
(0.0003)\end{array}$ & $\begin{array}{c}-0.0001 * * * \\
(0.0000)\end{array}$ & $\begin{array}{c}0.0008 * * \\
(0.0004)\end{array}$ \\
\hline Observations & $7,735,104$ & $6,280,801$ & $7,735,104$ & $1,652,425$ & $9,031,680$ & $7,554,617$ & $9,031,680$ & $2,343,622$ \\
\hline$R^{2}$ & 0.504 & 0.727 & 0.374 & 0.623 & 0.499 & 0.773 & 0.379 & 0.682 \\
\hline \multicolumn{9}{|l|}{ Panel C: Layoff Risk } \\
\hline Affected $_{i j} * \operatorname{Reform}_{t} * \operatorname{Risk}_{i}$ & $\begin{array}{c}-0.0076 * * * \\
(0.0005)\end{array}$ & $\begin{array}{c}0.0030 * * * \\
(0.0004)\end{array}$ & $\begin{array}{c}-0.0001 * * * \\
(0.0000)\end{array}$ & $\begin{array}{c}0.0018 * * * \\
(0.0005)\end{array}$ & $\begin{array}{c}-0.0060 * * * \\
(0.0004)\end{array}$ & $\begin{array}{c}0.0030 * * * \\
(0.0003)\end{array}$ & $\begin{array}{l}-0.0001 \\
(0.0001)\end{array}$ & $\begin{array}{c}0.0015 * * * \\
(0.0004)\end{array}$ \\
\hline Firm*Affected FE & yes & yes & yes & yes & yes & yes & yes & yes \\
\hline Firm*Month FE & yes & yes & yes & yes & yes & yes & yes & yes \\
\hline Age Group*Month FE & yes & yes & yes & yes & yes & yes & yes & yes \\
\hline Clustered SE & firm & firm & firm & firm & firm & firm & firm & firm \\
\hline Observations & $9,802,368$ & $7,684,813$ & $9,802,368$ & $1,905,973$ & $11,477,952$ & $9,459,770$ & $11,477,952$ & $2,790,225$ \\
\hline$R^{2}$ & 0.470 & 0.689 & 0.362 & 0.547 & 0.480 & 0.753 & 0.371 & 0.622 \\
\hline
\end{tabular}

This table reports changes in employment and wages around the reform in municipalities with above (columns I through IV) and below (columns V through VIII) median labor market informality. The dependent variable is the employment of workers affected or unaffected by the reform by firm $i$ in month $t$ over total employment in December 2014 in column I, the log average wage in column II, the number of workers hired relative to a firm's employment in December 2014 in column III, and the log average hiring wage in column IV. The variable Affected i $_{i j}$ takes the value of one for workers with fewer than two prior UI benefits spells and zero for workers with two or more prior

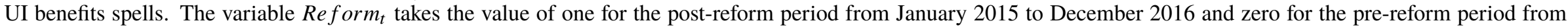
January 2013 to December 2014. Standard errors are reported in parentheses. The bottom part of the table reports information on fixed effects and the clustering of standard errors. $* * *, * *$, and $*$ denote statistical significance at the $1 \%, 5 \%$, and $10 \%$ levels, respectively. 
Table A.7: Industry Informality

\begin{tabular}{|c|c|c|c|c|c|c|c|c|}
\hline \multirow[b]{3}{*}{ Dep. Var:: } & \multicolumn{4}{|c|}{ High Informality } & \multicolumn{4}{|c|}{ Low Informality } \\
\hline & \multicolumn{2}{|c|}{ Employed Workers } & \multicolumn{2}{|c|}{ Hired Workers } & \multicolumn{2}{|c|}{ Employed Workers } & \multicolumn{2}{|c|}{ Hired Workers } \\
\hline & $\begin{array}{c}\text { ERate } \\
\text { I }\end{array}$ & $\begin{array}{c}\log (\text { wage }) \\
\text { II }\end{array}$ & $\begin{array}{c}\text { Hiring Rate } \\
\text { III }\end{array}$ & $\begin{array}{c}\log (\text { wage }) \\
\text { IV }\end{array}$ & $\begin{array}{c}\text { ERate } \\
\text { VI }\end{array}$ & $\begin{array}{c}\log (\text { wage }) \\
\text { VII }\end{array}$ & $\begin{array}{c}\text { Hiring Rate } \\
\text { VIII }\end{array}$ & $\begin{array}{c}\log (\text { wage }) \\
\text { IX }\end{array}$ \\
\hline \multicolumn{9}{|l|}{ Panel A: Credit Spread } \\
\hline Affected $_{i j} * \operatorname{Reform}_{t} * \operatorname{Risk}_{i}$ & $\begin{array}{c}-0.0020 * * * \\
(0.0004)\end{array}$ & $\begin{array}{c}0.0007 * * \\
(0.0003)\end{array}$ & $\begin{array}{c}-0.0001 * * * \\
(0.0000)\end{array}$ & $\begin{array}{l}0.0007 * \\
(0.0004)\end{array}$ & $\begin{array}{c}-0.0031 * * * \\
(0.0004)\end{array}$ & $\begin{array}{c}0.0009 * * * \\
(0.0003)\end{array}$ & $\begin{array}{c}-0.0003 * * * \\
(0.0001)\end{array}$ & $\begin{array}{c}0.0014 * * * \\
(0.0004)\end{array}$ \\
\hline $\begin{array}{l}\text { Observations } \\
R^{2}\end{array}$ & $\begin{array}{c}8,300,160 \\
0.487\end{array}$ & $\begin{array}{c}6,955,557 \\
0.745\end{array}$ & $\begin{array}{c}8,300,160 \\
0.374\end{array}$ & $\begin{array}{c}2,087,264 \\
0.554\end{array}$ & $\begin{array}{c}8,240,256 \\
0.516\end{array}$ & $\begin{array}{c}6,690,093 \\
0.782\end{array}$ & $\begin{array}{c}8,240,256 \\
0.354\end{array}$ & $\begin{array}{c}1,848,129 \\
0.635\end{array}$ \\
\hline \multicolumn{9}{|l|}{ Panel B: Default Provisions } \\
\hline Affected $_{i j} *$ Reform $_{t} * \operatorname{Risk}_{i}$ & $\begin{array}{c}-0.0031 * * * \\
(0.0004)\end{array}$ & $\begin{array}{c}0.0011 * * * \\
(0.0004)\end{array}$ & $\begin{array}{l}-0.0001 \\
(0.0001)\end{array}$ & $\begin{array}{c}0.0003 \\
(0.0005)\end{array}$ & $\begin{array}{c}-0.0047 * * * \\
(0.0004)\end{array}$ & $\begin{array}{c}0.0009 * * \\
(0.0003)\end{array}$ & $\begin{array}{c}-0.0001 * * * * \\
(0.0000)\end{array}$ & $\begin{array}{c}0.0015 * * * \\
(0.0005)\end{array}$ \\
\hline $\begin{array}{l}\text { Observations } \\
R^{2}\end{array}$ & $\begin{array}{c}8,300,160 \\
0.487\end{array}$ & $\begin{array}{c}6,955,557 \\
0.745\end{array}$ & $\begin{array}{c}8,300,160 \\
0.376\end{array}$ & $\begin{array}{c}2,087,264 \\
0.554\end{array}$ & $\begin{array}{c}8,240,256 \\
0.516\end{array}$ & $\begin{array}{c}6,690,093 \\
0.782\end{array}$ & $\begin{array}{c}8,240,256 \\
0.374\end{array}$ & $\begin{array}{c}1,848,129 \\
0.626\end{array}$ \\
\hline \multicolumn{9}{|l|}{ Panel C: Layoff Risk } \\
\hline Affected $_{i j} *$ Reform $_{t} * \operatorname{Risk}_{i}$ & $\begin{array}{c}-0.0085^{* * * *} \\
(0.0004)\end{array}$ & $\begin{array}{c}0.0035^{* * * *} \\
(0.0003)\end{array}$ & $\begin{array}{c}-0.0001 * * * \\
(0.0000)\end{array}$ & $\begin{array}{c}0.0011 * * \\
(0.0005)\end{array}$ & $\begin{array}{c}-0.0050 * * * \\
(0.0005)\end{array}$ & $\begin{array}{c}0.0019^{* * * *} \\
(0.0003)\end{array}$ & $\begin{array}{c}-0.0001 * * * \\
(0.0000)\end{array}$ & $\begin{array}{c}0.0019 * * * \\
(0.0005)\end{array}$ \\
\hline $\begin{array}{l}\text { Firm*Affected FE } \\
\text { Firm*Month FE } \\
\text { Age Group*Month FE } \\
\text { Clustered SE } \\
\end{array}$ & $\begin{array}{l}\text { yes } \\
\text { yes } \\
\text { yes } \\
\text { firm }\end{array}$ & $\begin{array}{l}\text { yes } \\
\text { yes } \\
\text { yes } \\
\text { firm }\end{array}$ & $\begin{array}{l}\text { yes } \\
\text { yes } \\
\text { yes } \\
\text { firm }\end{array}$ & $\begin{array}{l}\text { yes } \\
\text { yes } \\
\text { yes } \\
\text { firm }\end{array}$ & $\begin{array}{l}\text { yes } \\
\text { yes } \\
\text { yes } \\
\text { firm }\end{array}$ & $\begin{array}{l}\text { yes } \\
\text { yes } \\
\text { yes } \\
\text { firm }\end{array}$ & $\begin{array}{l}\text { yes } \\
\text { yes } \\
\text { yes } \\
\text { firm }\end{array}$ & $\begin{array}{l}\text { yes } \\
\text { yes } \\
\text { yes } \\
\text { firm }\end{array}$ \\
\hline $\begin{array}{l}\text { Observations } \\
R^{2}\end{array}$ & $\begin{array}{c}10,370,304 \\
0.475\end{array}$ & $\begin{array}{c}8,558,609 \\
0.715\end{array}$ & $\begin{array}{c}10,370,304 \\
0.369\end{array}$ & $\begin{array}{c}2,437,381 \\
0.562\end{array}$ & $\begin{array}{c}10,605,888 \\
0.957\end{array}$ & $\begin{array}{c}8,335,793 \\
0.760\end{array}$ & $\begin{array}{c}10,605,888 \\
0.367\end{array}$ & $\begin{array}{c}2,184,202 \\
0.640\end{array}$ \\
\hline
\end{tabular}

This table reports changes in employment and wages around the reform in industries with above (columns I through IV) and below (columns V through VIII) median labor market informality. The dependent variable is the employment of workers affected or unaffected by the reform by firm $i$ in month $t$ over total employment in December 2014 in column I, the log average wage in column II, the number of workers hired relative to a firm's employment in December 2014 in column III, and the log average hiring wage in column IV. The variable Af fected $d_{i j}$ takes the value of one for workers with fewer than two prior UI benefits spells and zero for workers with two or more prior UI benefits spells. The variable Reform $t$ takes the value of one for the post-reform period from January 2015 to December 2016 and zero for the pre-reform period from January 2013 to December 2014. Standard errors are reported in parentheses. The bottom part of the table reports information on fixed effects and the clustering of standard errors. ***, $* *$, and $*$ denote statistical significance at the $1 \%, 5 \%$, and $10 \%$ levels, respectively. 